JAKUB SITO

Warszawa, Instytut Sztuki PAN

\title{
Warszawscy rzeźbiarze czasów saskich $w$ roli projektantów
}

\footnotetext{
wym znakomitym, do dziś aktualnym tekstem poświęconym warsztatowi rzeźbiarskiemu doby baroku Konstanty Kalinowski wprowadził powyższą problematykę na grunt polskiej historii sztuki. We wstępie do swego studium esencjonalnie nakreślił istotę badawczą problemu:
}

W wielowiekowej historii rzeźby praktyka warsztatowa XVII i XVIII stulecia stanowi zjawisko odrębne, wyróżniające się przede wszystkim kolektywnym charakterem procesu twórczego. Uzus rzeźbiarski w okresie baroku zawierał wprawdzie wiele wcześniej stosowanych elementów procesu twórczego i posługiwał się repertuarem tradycyjnych zabiegów technicznych, wykorzystując zarówno warsztatową tradycję średniowiecza, jak i indywidualistyczne, kreatywne nastawienie artystów renesansu. Jednakże konieczność dostosowania się do zmienionych potrzeb odbiorców, między innymi realizacji w krótkim czasie dużych zleceń, spowodowała wykrystalizowanie się nowej praktyki wykonawczej, w której proces technicznej realizacji rzeźby przeszedł w znacznej mierze z rąk artystyprojektanta w ręce jego pomocników i współpracowników. Należy zarazem pamiętać, że praktyka warsztatowa w XVII i XVIII w., zróżnicowana w poszczególnych krajach Europy, zdeterminowana była $\mathrm{w}$ znacznej mierze zarówno miejscową tradycją jak i organizacją rynku sztuki, a we Francji i krajach niemieckich dodatkowo stymulowały ją reguły biurokratycznego systemu monarszego mecenatu. Do czasu najnowszych badań nad zjawiskiem warsztatu rzeźbiarskiego, zainicjowanych w końcu lat 70. XX w., artystę tej profesji historia sztuki traktowała przede wszystkim jako twórcę ujawniającego w swych dziełach własną, oryginalną ekspresję. O takim indywidualistycznym widzeniu twórczości rzeźbiarskiej baroku decydowała zarówno renesansowa, neoplatońska koncepcja „boskiego” twórcy-kreatora (jako przykłady przywoływano postacie Michała Anioła czy Rafaela), a także romantyczna legenda artysty-samotnego geniusza. Cały obszar zagadnień warsztatowych, determinujących $\mathrm{w}$ istotnej mierze $\mathrm{w}$ wypadku rzeźby formalną stronę dzieła, pozostawał poza horyzontem zainteresowań badawczych zarówno globalnej, jak i polskiej historii sztuki. Dopiero wiedza o warsztacie barokowego rzeźbiarza pozwala w pełni uwzględnić wszystkie uwarunkowania towarzyszące powstawaniu dzieła rzeźbiarskiego w XVII i XVIII stuleciu ${ }^{1}$.

\footnotetext{
${ }^{1}$ Konstanty KALINOWSKI, „Warsztat barokowego rzeźbiarza”, Artium Quaestiones, 1995, t. VII, s. 103-104. Na temat aspektów warsztatowych i technicznych rzeźby nowożytnej pisali m.in.: Jack C. RICH, The Materials and Methods of Sculpture, New York 1958; Rudolf WITTKOWER, The Sculptor's Workshop. Tradition and Theory from Renaissance to the Present, Glasgow 1974; id., Sculpture: Processes and Principles, London 1977; Giulio Carlo ARGAN, „Sculpture” [w:] Encyclopedia of World Art, t. XII, London 1966, szp. 816-840 (tamże obszerna literatura); id.,
} 
Jednym z zasadniczych aspektów działalności owego warsztatu jest kwestia projektu dzieła sztuki, w którym rzeźba odgrywała zasadniczą rolę - zarówno samej figury ludzkiej, czy grupy figuralnej, jak i jej architektonicznej obudowy w rodzaju portalu, tympanonu, ogrodzenia, bramy, ołtarza, nagrobka, ambony czy innych dzieł świeckich i kościelnych.

Jak słusznie podnosił Konstanty Kalinowski, to projekt rysunkowy lub plastyczny zaaprobowany przez zleceniodawcę, bywał najczęściej punktem wyjścia do realizacji dzieła rzeźbiarskiego: „Od artysty zależało, czy przedkładał on klientowi rysunek czy też modelletto przyszłego dzieła. Znamy przypadki, że ubiegający się o to samo zlecenie składali zarówno projekty rysunkowe, jak i plastyczne modelletta. Sytuacja taka zaistniała np. w 1735 r., kiedy Edmé Buchardon, starający się o zlecenie na rzeźby ogrodowe dla Duca d'Antin, wykonał rysunek, a jego konkurent, Lambert Sigisbert Adam bozzetto"'. Kalinowski wskazał również na podobny przypadek nagrobka drugiego diuka Argyll w Westminster Abbey, do którego François Louis Roubiliac przedstawił bozzetto, a jego konkurent John Michael Rysbrack projekt rysunkowy ${ }^{3}$. Z kolei Giovanni Giuliani pomijał - jak się wydaje - fazę rysunku, bazując na terakotowych modelach zachowanych do dziś w dziesiatkach egzemplarzy ${ }^{4}$. W praktyce francuskich Bâtiments du Roi stosowano przeważnie projekty rysunkowe (il. 1).

Projekty najznamienitszych dzieł plastycznych zamawiano bardzo często nie u rzeźbiarzy, a u architektów. Na przykład Johann Bernhard Fischera von Erlach zaprojektował okazałe nagrobki Johanna Wenzela Wratislawa von Mitrowitz w kościele św. Jakuba w Pradze (realizowany przez Ferdynanda Maximiliana Brokoffa) i Johanna Georga Wolffa w kościele św. Elżbiety we Wrocławiu (wykonany przez tegoż Brokoffa, jego pomocnika

\footnotetext{
„Sculpture”, [w:] The Encyclopedia of Visual Art, t. X, London 1983, s. 100-103 (tamże literatura). Zob. też katalogi wystaw: Die Bildhauerfamilie Schwanthaler 1633-1858. Vom Barock zum Klassizismus, Augustinerchorherrenstift Reichersberg am Inn 1974; Die Bildhauerfamilie Zürn 1585-1724, Braunau am Inn 1979; Bayerische Rokokoplastik. Vom Entwurf zur Ausfiihrung, Bayerisches Nationalmuseum, München 1985 (szczególnie wartościowy artykuł Peter VOLK, Bildhauerentwurfe des bayerischen Rokoko, s. 9-13). Ponadto: Jennifer MONTAGU, „Disegni, Bozzetti, Legnetti, and Modelli in Roman seicento Sculpture”, [w:] Entwurf und Ausführung in der europäischen Barockplastik. Beiträge zum Internationalen Kolloquium des Bayerischen Nationalmuseums und des Zentralinstituts für Kunstgeschichte, München 24-26 Juni 1985, red. Peter VOLK, München 1986, s. 9-20; Helga TRATZ, ,Werkstatt und Arbeitsweise Berninis", Römisches Jahrbuch für Kunstgeschichte, 1988, nr 23/24, s. 337-374; Jennifer MONTAGU, Roman Baroque Sculpture. The Industry of Art, New Haven-London 1992; Studien zur Werkstattpraxis der Barockskulptur im 17. und 18. Jahrhundert, red. Konstanty KALINOWSKI, Poznań 1992 (tu m.in. Oldřich J. BLAŽIČEK, Bildhauerwerkstatt des Böhmischen Barock, s. 13-21; Hans-Peter TRENSCHEL, Bozzetti aus den Werkstätten der Würzburger Bildhauers des 18. Jahrhunderts, s. 103-113, Ingeborg SCHEMPER-SPARHOLZ, Barockbildhauer im Dienst der Klöster in Österreich, s. 327-340); Jan K. OSTROWSKI, „Z problematyki warsztatowej i atrybucyjnej rzeźby lwowskiej w XVIII wieku", [w:] Sztuka kresów wschodnich. Materiały sesji naukowej, Kraków, marzec 1994, red. Jan K. OSTROWSKI, Kraków 1994, s. 79-104; Nicholas PENNY, The Materials of Sculpture, New Haven-London 1993; KALINOWSKI, „Warsztat barokowego rzeźbiarza...”, s. 103-140; Peter ROCKWELL, Stanley ROSENFELD, Heather HANLEY, The Complete Marble Sleuth, Sunny Isles Beach 2004; Arkadiusz WAGNER, Warsztat rzeźbiarski Chrystiana Bernarda Schmidta na Warmii, Olsztyn 2007 (zwłaszcza rozdział Organizacja i technika pracy, s. 130-168); Tadeusz ŻUCHOWSKI, Poskromienie materii. Nowożytne zmagania rzeźbiarzy z marmurem kararyjskim. Michat Anioł, Bernini, Canova, Poznań 2010 (tamże obszerna literatura); Jakub SITO, Wielkie warsztaty rzeźbiarskie Warszawy doby saskiej. Modele kariery - formacja artystyczna - organizacja produkcji, Warszawa 2013.

2 Anne-Lise DESMAS, Édouard KOPP, Guilhem SCHERF, Edmé Bouchardon (1798-1772). Une idée du beau, Paris 2016, s. 208-210. Cyt. za KALINOWSKI, „Warsztat barokowego rzeźbiarza...”, s. 135-136.

${ }^{3}$ Malcolm BAKER, „Roubiliac's Argyll Monument and the Interpretation of Eighteenth-Century Sculptor's Designs”, The Burlington Magazine, 134: 1992, nr 1077, s. 785-797.

${ }^{4}$ Luigi A. RONZONI, Giovanni Giuliani (1664-1744), red. Johann KRÄFTNER, t. 1: Essays, t. 2: Katalog, MünchenBerlin-London-New York 2005, passim.
} 
1. Charles Le Brun, projekt rzeźbiarskiego panneau do pałacu $w$ Vaux-le-Vicomte, rysunek sangwinq i tuszem, podmalowany akwarela, ok. 1656-1658. Sztokholm, Nationalmuseum, nr inwent. NMH CC I 34. Fot. Cecylia Heisser

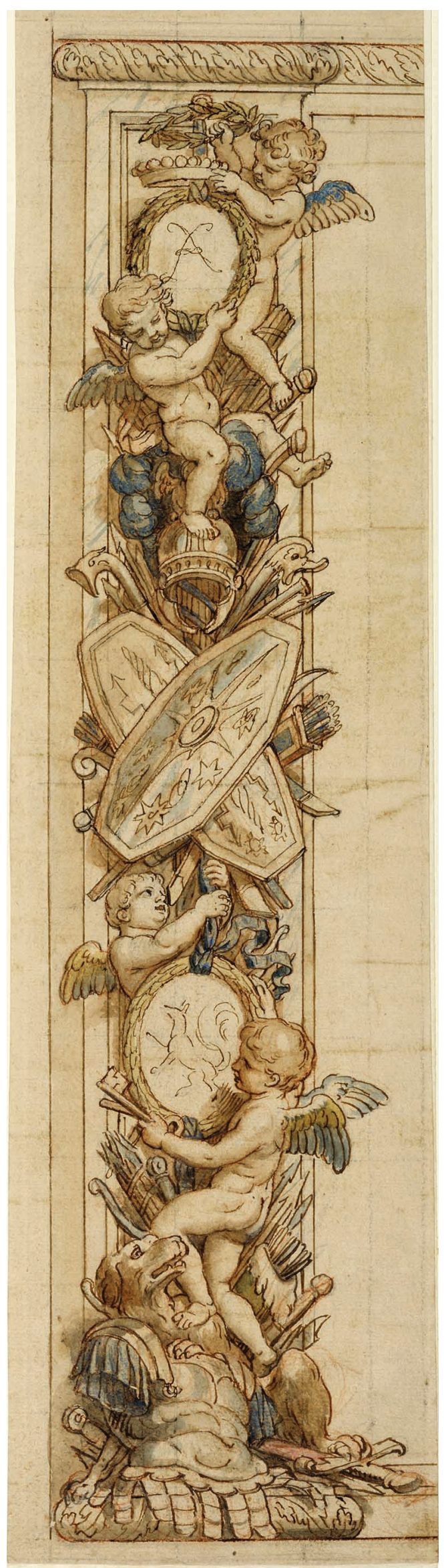


Samuela Pardzyńskiego i kamieniarza Adama Karingera) ${ }^{5}$. Architekci projektowali także dekoracje teatralne i okolicznościowe, jak np. Lodovico Burnacini dla słynnej Pestsäule w Wiedniu (także Johann Bernhard Fischer von Erlach czy Paul Strudel; il. 2) ${ }^{6}$. Wiele realizacji zlecano malarzom, np. Michaelowi Willmanowi projekt ołtarza głównego dla cysterskiego kościoła w Lubiążu, wykonywany przez Matthiasa Steinla w 1681 r. ${ }^{7}$ We Francji projekty rzeźbiarskie realizowane przez Bâtiments $d u$ Roi były najczęściej dziełem Charles'a Le Bruna ${ }^{8}$. Projektantami prospektów organowych bywali z reguły organmistrze, umiejący dostosować ich kształt do potrzeb instrumentu ${ }^{9}$. Miał więc rację Kalinowski, pisząc że „rola rzeźbiarza - wykonawcy wystroju figuralnego w procesie powstawania wielkich, prestiżowych dzieł - sprowadzała się w tych przypadkach do funkcji realizatora cudzych projektów"10.

Sami rzeźbiarze również projektowali ołtarze, epitafia czy figury ogrodowe. Wystarczy przywołać nazwiska Gianlorenza Berniniego ${ }^{11}$, Alessandra Algardiego ${ }^{12}$, François Duquesnoy $^{13}$, Ferdinanda Maximiliana Brokoffa ${ }^{14}$, Johanna Baptisty Strauba ${ }^{15}$, Raffaela Donnera $^{16}$, Baltasara Permosera ${ }^{17}$ czy Ignacego Günthera ${ }^{18}$. Rzeźbiarze-projektanci to przede wszystkim artyści stale zatrudniani przez dwór (władcy lub arystokraty), wysokie duchowieństwo czy klasztory ${ }^{19}$, twórcy cieszący się dużą renomą lub działający na peryferiach kulturowych, gdzie nie napotykali na znaczącą konkurencję architektów i budowniczych. Jednakże pomniejszenie roli rzeźbiarzy $w$ procesie realizacji wielkich dzieł w oczywisty sposób osłabiało ich motywację innowacyjną. Podporządkowanie się obcym projektom wymagało od nich raczej rozwiniętych zdolności adaptacyjnych niż pielęgnowania indywidualnego stylu. Przyjęcie przez zleceniodawcę projektu do realizacji nie oznaczało bynajmniej, że jego wykonanie będzie przekazane w ręce projektanta. Gromadzone w wyniku konkursu lub kilku równoległych zleceń projekty pozostawały do dyspozycji zleceniodawcy i od niego wyłącznie zależał wybór realizatora lub realizatorów.

\footnotetext{
${ }^{5}$ Oldřich J. BLAŽIČEK, Ferdinand Brokoff, Praha 1976, s. 107, 127.

${ }^{6}$ Gertraut SCHIKOLA, „Wiener Plastik der Renaissance und des Barock”, [w:] Geschichte der Stadt Wien (N.R.,VII.,1), Wien 1970, s. 104.

${ }^{7}$ Konstanty KALINOWSKI, Rzeźba barokowa na Ślasku, Warszawa 1986, s. 71, 198-199.

${ }^{8}$ Jennifer MONTAGU, „Charles Le Brun and his Sculptors. A Reconsideration in the Light of Some Newly Identified Drawings", Burlington Magazine, 118: 1976, nr 875, s. 88-94.

${ }^{9}$ Marcin ZGLIŃSKI, Nowożytny prospekt organowy i jego twórcy, Warszawa 2012 (zob. szczególnie rozdział Projekt, s. 38-337).

${ }^{10}$ KALINOWSKI, Warsztat barokowego rzeźbiarza..., s. 136. Por. Robert ENGGASS, „Un problème du baroque romain tardif. Projets de sculptures par des artistes non sculpteurs", Revue de l'art, 1976, nr 31, s. 21-32; MONTAGU, „Disegni, Bozzetti, Legnetti, and Modelli...”, s. 9-13.

${ }^{11}$ Roberto PANE, Bernini architetto, Venezia 1953; Franco BORSI, Bernini architetto, Milan 1980; Irving LAVIN, Bernini and the Unity of the Visual Arts, New York 1980; Gian Lorenzo Bernini, architetto e l'architettura europea del Sei-Settecento, red. Gianfranco SPAGNESI, Marcello FAGIOLO, Roma 1983-1984; Rudolf WITTKOWER, Gian Lorenzo Bernini. The Sculptor of the Roman Baroque, London 1997; Felix ACKERMANN, Die Altäre des Gian Lorenzo Bernini. Das barocke Altarensemble im Spannungsfeld zwischen Tradition und Innovation, Petersberg 2007.

12 Jennifer MONTAGU, Alessandro Algardi, New Haven-London 1985.

${ }^{13}$ Marion BOUDON-MACHUEL, Francois du Quesnoy 1597-1643, Paris 2005.

${ }^{14}$ BLAŽIČEK, Ferdinand Brokof..., passim; id., „Modellpraxis in der böhmischen Barockskulptur”, [w:] Entwurf und Ausführung..., s. 85-102.

15 Peter VOLK, Johann Baptist Straub, München 1984.

${ }^{16}$ Georg Raphael Donner 1693-1741, red. Michael KRAPF, [kat. wyst.], Österreichische Gallerie, Wien 1993.

${ }^{17}$ Sigfried ASCHE, Balthasar Permoser. Leben und Werk. Berlin 1978.

18 Peter VOLK, Ignaz Günther. Vollendung des Rokoko, Regensburg 1991.

${ }^{19}$ Martin WARNKE, Hofkünstler. Zur Vorgeschichte des modernen Kiinstlers, Koln 1995, s.241-252
} 


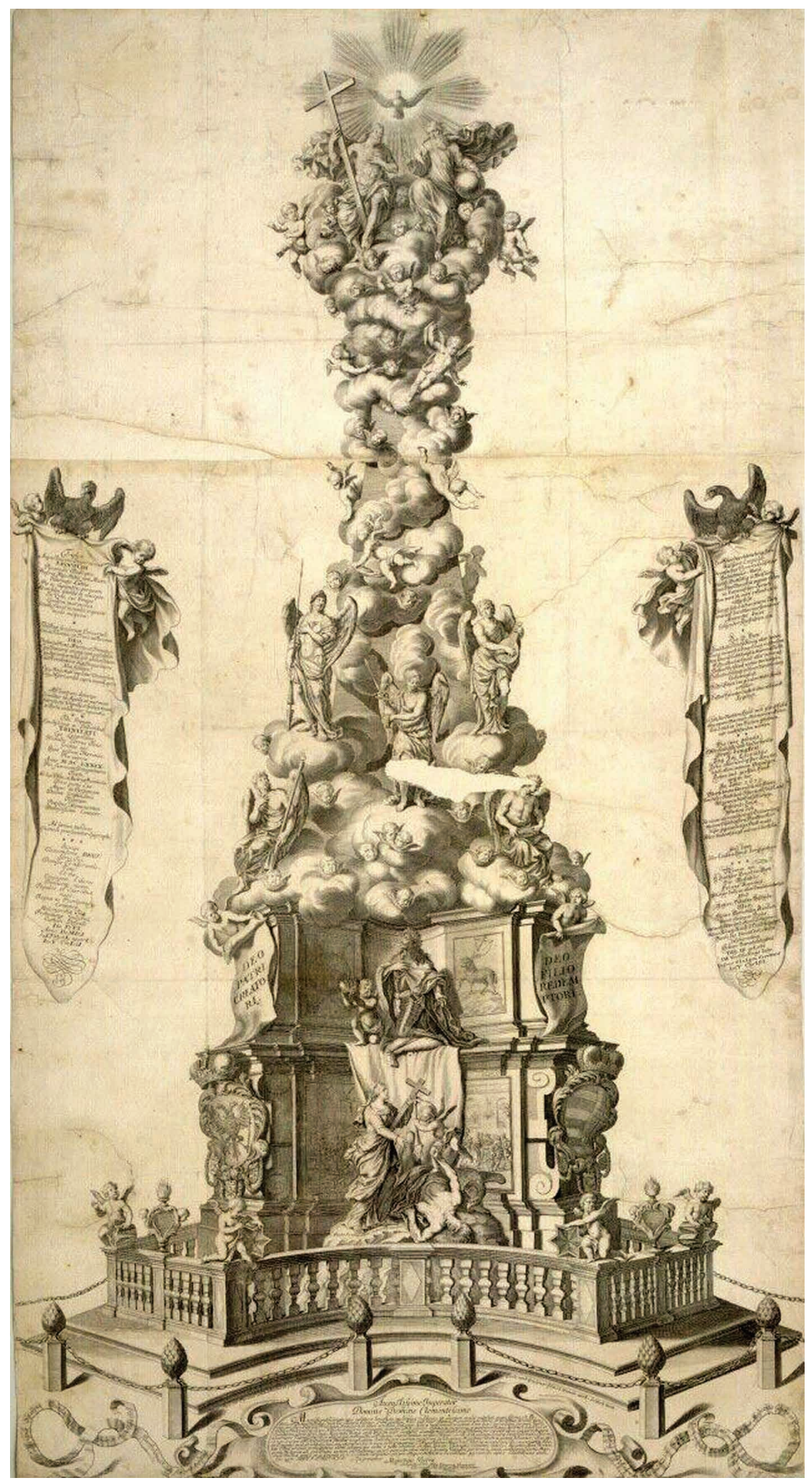

2. Lodovico Burnaccini, Widok Pestsäule w Wiedniu, miedzioryt Bartholomäusa Kiliana, 1679. Fot. ze zbiorów autora 
Często też projekty te stanowiły materiał do ostatecznego opracowania tematu, nierzadko zlecanego innemu rzeźbiarzowi. Charakterystycznym przykładem takiego procederu może być proces wykonywania figury św. Jana Nepomucena na Moście Karola w Pradze, do której rysunkowy projekt wykonał architekt Jean-Baptiste Mathey, bozzetto rzeźbiarz Matthias Rauchmiller, pełnowymiarowy model dla realizacji odlewu rzeźbiarz Johann Brokoff ${ }^{20}$, sam zaś odlew był dziełem norymberskiej pracowni Hieronymusa Herolda ${ }^{21}$. Ferdinand Tietz, wykonując nagrobek Franza Georga von Schönborna w katedrze w Trewirze, realizował projekt Johanna Wolfganga van der Auwery ${ }^{22}$. Przywoływany tu klikukrotnie Konstanty Kalinowski zauważył, że „w przypadku wielkich zamówień wymagających udziału znacznej liczby wykonawców, częstym zjawiskiem było angażowanie do realizacji projektu nie jednego zespołu, lecz kilku warsztatów, ewentualnie także podzlecanie części pracy różnym warsztatom, specjalistom (stolarzom, kamieniarzom, odlewnikom) lub rzeźbiarzom. Wszystkie wielkie i prestiżowe projekty Berniniego realizowali rzeźbiarze niepowiązani z nim zależnością warsztatowa, lecz ofiarowujący swe usługi na wolnym rynku wykonawczym giovani lub operarii, tacy jak Antonio Raggi, Domenico i Giovanni de Rossi, Domenico Prestinari, Giovanni Battista Morelli, Antonio i Cosimo Fancelli, Ercole Ferratta, Andrea Bolgi"23. Niektórzy z nich z czasem uzyskiwali dla swoich pracowni status wziętych warsztatów rzeźbiarskich, jak Ercole Ferratta, inni pozostawali na trwałe w roli jedynie realizatorów.

Rzeźbiarze doby baroku poszukiwali wzorów, schematów wizualnych i modeli wzorcowych w dziełach antycznych rozpowszechnianych przez albumy graficzne i w prestiżowych realizacjach współczesnych. Stosowane formuły stylowe czy przyjmowane wzorce ułatwiały im wykonanie konkretnego zamówienia, podsuwając warianty rozwiązań opracowywanego tematu zarówno te powszechnie stosowane i już zaakceptowane, jak i nowatorskie. Rzeźbiarz zmuszony był już w momencie wstępnego komponowania dzieła liczyć się z konkretnymi postulatami zleceniodawcy. Chcąc uzyskać zamówienie musiał dostosować swój repertuar do oczekiwań klienta, nie tylko starając się możliwie atrakcyjnie zaprezentować swe dzieła, lecz także liczyć się z jego estetycznymi preferencjami.

Zagadnienie udziału rzeźbiarzy okresu baroku w projektowaniu dzieł sztuki, w tym realizowanych przez siebie figur, nie było na gruncie polskim przedmiotem osobnych studiów. Pojawiały się na ten temat jedynie drobne wzmianki w pracach szerszych, w monografiach tak samych rzeźbiarzy, jak i architektów, w syntetycznych omówieniach poszczególnych ośrodków artystycznych czy opracowaniach dotyczących mecenatu artystycznego ${ }^{24}$. W największym stopniu spostrzeżenia te dotyczyły środowiska warszawskiego, co nie powinno dziwić zważywszy na jego stosunkowo niezłe rozpoznanie (na tle

\footnotetext{
${ }^{20}$ Oskar POLLAK, Johann und Ferdinand Maximilian Brokoff. Ein Beitrag zur Geschichte der Österreichischen Barockplastik, Prag 1910; Oldřich J. BLAŽIČEK, Karli̊v Most. Vytvarná kronika Karlova mostu, Praha 1955; Ivo KOŘÁN, „Brokof Jan”, [w:] Biograficky slovník českych zemí, t. 7: Bra-Brum, red. Jaroslav RICHTER, Praha 2007. ${ }^{21}$ Veronika BIRKE, Mathias Rauchmiller. Leben und Werk, Wien 1981; Johannes von Nepomuk 1393-1993, [kat. wyst.], Bayerisches Nationalmuseum München, München 1993, s. 114-123, poz. kat. 24-27.

22 Bernd W. LINDEMANN, „Zeichen und Modeli in Oeuvre des F. Tietz”, [w:] Studien zur Werkstattpraxis..., s. 64

${ }^{23}$ KALINOWSKI, Warsztat barokowego rzeźbiarza..., s. 137. Por. MONTAGU, Roman Baroque Sculpture..., s. 126-150.

${ }^{24}$ Aldona BARTCZAKOWA, Jakub Fontana. Architekt warszawski XVIII wieku, Warszawa 1970; Anna OLEŃSKA, Jan Klemens Branicki ,sarmata nowoczesny”. Kreowanie wizerunku poprzez sztuke, Warszawa 2012; Anna DETTLOFF, Rzeźba krakowska drugiej połowy wieku XVIII. Twórcy, nurty i tendencje, Kraków 2013; SITO, Wielkie warsztaty rzeźbiarskie...; Rafał NESTOROW, Pro domo et nomine suo. Fundacje i inicjatywy artystyczne Adama Mikołaja i Elżbiety Sieniawskich, Warszawa 2016; Bartłomiej ŁYCZAK, Toruński cech rzeźbiarski i snycerka na obszarze jego oddziaływania w latach 1695-1793, Warszawa 2018.
} 
innych ośrodków w Rzeczypospolitej), jak i na wysoki poziom produkcji. W przypadku Warszawy zainteresowanie badaczy sięgało czasów wazowskich. Pionierska rola przypadła tu Mariuszowi Karpowiczowi, który w swoim artykule z 1991 r. opisał współpracę dwóch działających w Rzeczypospolitej rzymskich artystów połowy XVII w.: architekta Giovanniego Battisty Gisleniego i rzeźbiarza Francesca Rossiego ${ }^{25}$. Analizując rysunki projektowe tego pierwszego i porównując je z realizacjami, doszedł do wniosku, że obaj artyści stanowili partnerski tandem. Architekt liczył się z rzeźbiarzem, z jego inicjatywą i inspiracjami często pozostawiając mu jako świetnie obeznanemu ze sztuką barokowego Rzymu wolną rękę w kreacji partii czysto rzeźbiarskich. Z kolei Gisleni wychowany zasadniczo na sztuce wczesnego baroku, ale wprowadzający też rozwiązania bardziej zaawanasowane, w typie Berniniego czy Cortony, ogromnie cenił sobie Rossiego, bliższego klasycyzującej sztuce Algardiego ${ }^{26}$.

Na pierwsze lata XVIII w. (czas wojny północnej i wielkiej zarazy) przypadł w Warszawie zastój w inwestycjach budowlanych (zwłaszcza pałacowych) i niemal całkowite wycofanie z „rynku” rzeźbiarzy-figuralistów. Współpracownicy i uczniowie rzeźbiarzy z czasów Jana III rozjechali się po Polsce ${ }^{27}$, nielicznie wówczas budowane pałace i kościoły pozostawały bez wyposażenia. Dopiero w drugiej dekadzie stulecia zaczął działać w Warszawie prężny i wzięty warsztat, czy raczej przedsiębiorstwo rzeźbiarskie, pod kierunkiem Bartłomieja Michała Bernatowicza (zm. 1730). Warsztat ten opanował większość produkcji w Warszawie od około 1715 do 1730 r. Wykonywał prace rzeźbiarskie, głównie ołtarze, ale także ambony i nagrobki dla stołecznych kościołów klasztornych - jezuitów, dominikanów, franciszkanów, paulinów, pijarów, trynitarzy i innych ${ }^{28}$.

Spośród udokumentowanych archiwalnie dzieł warsztatu Bernatowicza najwcześniej, bo w 1718 r., powstał zespół ołtarza głównego i pary ołtarzy przytęczowych w kościele Jezuitów w Brześciu. Fundatorem był Jan Fryderyk Sapieha, kasztelan trocki ${ }^{29}$. Kościół oraz jego wyposażenie nie istnieje od 2. połowy XIX w., jednak zachował się obszerny kontrakt dotyczący prac wykonanych przez warsztat Bernatowicza. Ów niezwykle ciekawy dokument pozwala na częściowe wniknięcie w metodę pracy rzeźbiarza na wczesnym etapie jego twórczości. Kontrakt ten odsłania tajniki projektowania ołtarza przez samego rzeźbiarza, o czym dokument wyraźnie wspomina, a także pozwala odtworzyć świat wzorów, na jakich artysta się opierał. Fundator uzgodnił ze snycerzem ostateczny kształt brzeskiego ołtarza głównego i ołtarzy przytęczowych odwołując się aż do sześciu warszawskich obiektów w czterech świątyniach, przeważnie niewiele starszych od samego zamówienia. Były to konkretne motywy o ściśle ustalonym kształcie, takie jak kolumny, kapitele, rama obrazu, przeźrocza z popiersiami czy relikwiarze. Jako wzór dla znacznej części z nich posłużyły dzieła projektu Tylmana van Gameren, np. ołtarz główny w kościele Św. Krzyża z kolumnami o specyficznym ornamentalnym kanelowaniu à la française ${ }^{30}$.

\footnotetext{
${ }^{25}$ Mariusz KARPOWICZ, „Giovani Battista Gisleni i Francesco de’Rossi. Z dziejów współpracy architekta i rzeźbiarza”, Kwartalnik Architektury i Urbanistyki, XXXVI: 1991, nr 1, s. 3-21.

${ }^{26}$ KARPOWICZ, „Giovani Battista Gisleni...”, s. 15-16.

${ }^{27}$ Rzeźbiarze warszawscy po śmierci Jana III działali m.in. we Lwowie; zob. Володимир С. АЛЕКСАНДРОВИЧ, „Скульптура”, [w:] Історія українського мистеитва, red. Ганна СКРИПНИК, t. III: Мистецтвво другої половини XVI-XVIII століття, red. Дмитро В. СТЕПОВИК, Київ 2011, s. 407-408; SITO, Wielkie warsztaty rzeźbiarskie..., s. 149.

${ }^{28}$ SITO, Wielkie warsztaty rzeźbiarskie..., s. 23-149.

${ }^{29}$ Marta i Wojciech BOBERSCY, „W kręu fundacji Jana Fryderyka Sapiehy (1680-1751)”, [w:] Między Padwa a Zamościem. Studia z dziejów sztuki i kultury artystycznej ofiarowane prof. Jerzemu Kowalczykowi, Warszawa 1993, s. 75-91; SITO, Wielkie warsztaty rzeźbiarskie..., s. 31-33.
} 
Wspomniano wyraźnie, że „Słupów [kolumn] ma być u niego cztery, tak rżniętych jako u Wielkiego Ołtarza OO. Misyonarzów Świętego Krzyża"31. W ołtarzykach bocznych „miały być w owalach wydrążonych osoby po pas S. Quiryna y Faustyna z takiemi ornamentami iako u OO. Teatynów Warszawskich nad zakrystią”, czyli popiersia świętych w owalnych, drążonych niszach na wzór tych z kaplicy Teatynów warszawskich projektu Tylmana z około 1697 r. $^{32}$ „,Trumienki na S. Relikwie” w tychże ołtarzykach miały być „iako u S. Felicissimy, przy ornamentach w Abrysie wyrażonych" ${ }^{33}$, czyli miały powtarzać srebrny relikwiarz św. Felicissimy ze stołecznego kościoła Św. Krzyża, paryskiej roboty Guillaume'a Jacoba, wykonany najpewniej znów według projektu Tylmana ${ }^{34}$. Omawiający brzeską fundację Marta i Wojciech Boberscy uznali, że zarówno ów zasób elementów proweniencji Tylmanowskiej, jak i wszystkie warszawskie „cytaty” artystyczne zostały podyktowane rzeźbiarzowi przez samego fundatora. Niewatpliwie to on ostatecznie decydował o kształcie dzieła czy o dokonywanych wyborach, te ostatnie jednak, jak sądzę, mogły być przynajmniej częściowo sugerowane przez wykonawcę, ponieważ przy niektórych z nich Bernatowicz sam wcześniej pracował, jak choćby przy ołtarzu św. Ignacego w kościele Jezuitów w Warszawie (ok. 1715-1716) ${ }^{35}$, przywoływanym w kontrakcie aż dwukrotnie jako wzór. Tym niemniej to właśnie rzeźbiarzowi przypadło w udziale wykonanie ostatecznego projektu ołtarza. Kreatywności Bernatowicza nie umniejsza znaczna liczba przywoływanych cytatów, rzeźbiarz musiał przecież scalić je w jedno posiłkując się przy tym własną wyobraźnią projektową.

Jak wskazywałem w swojej pracy z 2013 r., Bartłomiej Bernatowicz - sam będąc snycerzem generacji przełomu XVII i XVIII w. - zatrudniał co najmniej dwóch wyróżniających się poziomem anonimowych dotąd rzeźbiarzy, będących odrębnymi, wyrazistymi osobowościami artystycznymi, którzy przybyli przed rokiem 1720 niemal na pewno z Pragi - ówcześnie jednego z najważniejszych ośrodków środkowoeuropejskich ${ }^{36}$. Można przypuszczać, że wpływ na ich twórczość miał krąg italianizującej rzeźby wielkich prażan - Ferdinanda Maximiliana Brokoffa i Matthäusa Wenzela Jäckla. Obaj anonimowi rzeźbiarze praktycznie zdecydowali o randze artystycznej warszawskiego warsztatu, przede wszystkim ze względu skalę swego talentu, wszechstronność i wyrazisty italianizm, nawiązujący poprzez swych praskich preceptorów pośrednio do Berniniego i jego naśladowców w rzeźbie włoskiej. Obaj ci rzeźbiarze wnieśli zupełnie nowe, nieznane dotąd w Warszawie praskie rozwiązania plastyczne i kompozycyjne. Monumentalizm osiagnięty przez zwartą kompozycję bryły, zamknięty, spokojny rysunek konturu, masywna forma plastyczna i podkreślana statyczność - to naczelne cechy tego stylu. W ich twórczości ogromną rolę odgrywa także tkanina, traktowana jako ważny, niezbywalny element artystycznego wyrazu, który potęguje wrażenie ruchu i dynamizuje kompozycję. Takie

\footnotetext{
${ }^{30}$ Por. Katarzyna WARDZYŃSKA, „Ołtarze: główny 1699-1700, ss. Felicissimy i Genowefy 1704, Trójcy Św. i Najśw. Sakramentu 1720-1721", [w:] Serce Miasta. Kościót Świętego Krzyża w Warszawie, red. Kazimierz SZTARBAŁŁO, Michał WARDZYŃSKI, Warszawa 2010, s. 161-191.

${ }^{31}$ BOBERSCY, „W kręgu fundacji Jana Fryderyka Sapiehy...”, s. 78.

32 Ibid., s. 78.

33 Ibid., s. 79.

${ }^{34}$ Jerzy ŻMUDZIŃSKI, Projekt trumny relikwiarzowej św. Felicissimy dla oltarza w kościele Św. Krzyża w Warszawie, [w:] Święto baroku. Sztuka w stużbie prymasa Michała Stefana Radziejowskiego (1645-1705), red. Jerzy ŻMUDZIŃSKI, [kat. wyst.], Muzeum-Pałac w Wilanowie, Warszawa 2009, s. 302-303; WARDZYŃSKA, „Ołtarze...”, s. 164, 174-183.

${ }^{35}$ SITO, Wielkie warsztaty rzé́biarskie..., s. 33-35.

${ }^{36}$ Ibid., s. 107-132.
} 


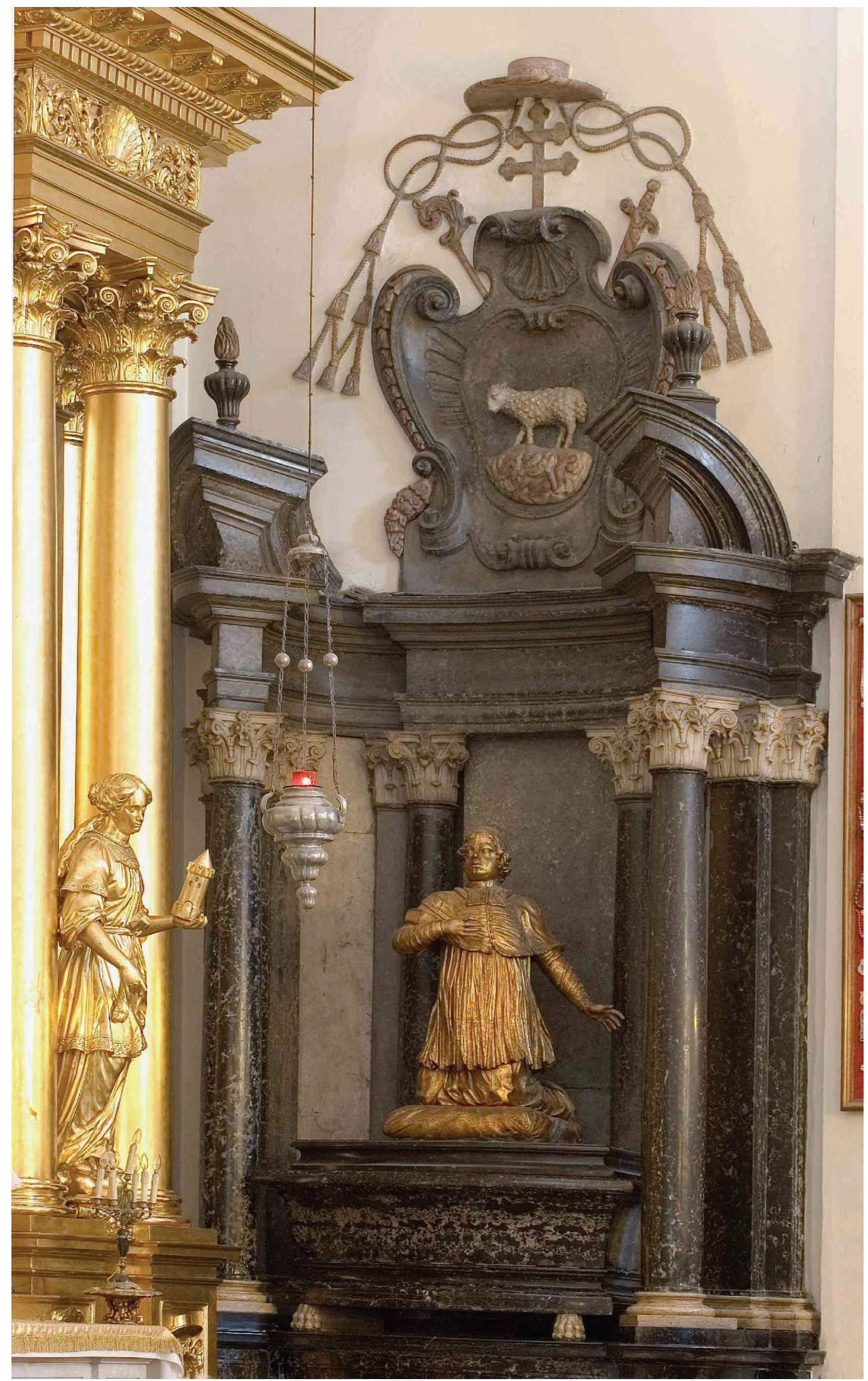

3. Carlo Antonio Bay (projekt), czeski (?) rzeźbiarz z warsztatu Bartłomieja Michała Bernatowicza (wspótprojekt i wykonanie rzeźby), nagrobek kardynała Michała Stefana Radziejowskiego w kościele Św. Krzyża w Warszawie, 1719-1721. Fot. Jakub Sito 
rzeźby jak posag Chrystusa Zmartwychwstałego w ołtarzu z kościoła Pijarów (nawiązujący pośrednio do figury św. Longina dłuta Berniniego), rzeźby ołtarza w Kodniu (będące refleksem posagów z watykańskiej Cathedra Petri) czy figura z nagrobka kardynała Michała Radziejowskiego w kościele Św. Krzyża (wywodząca się z rzymskiej barokowej rzeźby nagrobnej) dowodzą znajomości najlepszych wzorów włoskich stanowiących w tym czasie w Warszawie całkowitą nowinkę.

W literaturze zwraca się od pewnego czasu uwagę na związki, czy raczej znamiona współpracy zawodowej, łączące Bartłomieja Michała Bernatowicza z Carlem Antoniem Bayaem - najwybitniejszym warszawskim architektem pierwszego czterdziestolecia XVIII w., pochodzącym z północnych Włoch, a wykształconym w Rzymie około 1700 r., będącym wychowankiem Andrei Pozza, mającym dobre rozeznanie w projektach kręgu Carla Fontany ${ }^{37}$. Związki te pierwszy zauważył Mariusz Karpowicz rozpatrujący szereg prac rzeźbiarskich Bernatowicza jako realizowanych w ramach projektów architektonicznych Baya. Uczony ów znakomicie przeanalizował zwłaszcza przypadek nagrobka kardynała Michała Radziejowskiego z lat 1719-1721 ze stołecznego kościoła Św. Krzyża (il. 3). Projekt tego monumentu został starannie opracowany tak pod względem architektonicznym, jak i rzeźbiarskim. Forma figury zmarłego była niewątpliwie efektem współpracy architekta i rzeźbiarza. Wynikiem uzgodnień między nimi był najpewniej ogólny układ posagu, jego miejsce w kompozycji nagrobka, zastosowane zabiegi specjalne, takie jak rezygnacja z symetrii, nienaturalnie silny skręt tułowia i przeciwstawny skręt głowy, spełniające rolę optycznych korektur. Były one niezbędne wobec trudnych warunków ekspozycyjnych, jako że pole właściwego oglądu dzieła jest nader ograniczone (u wylotu lewej nawy bocznej i w ramieniu transeptu, w obu przypadkach pod silnym ukosem). Nasuwa się pytanie, czy wobec tak doskonałej współpracy architekta i rzeźbiarza, przypominającej praktyki znane z XVIIwiecznego Rzymu, nie należałoby wziąć tu pod uwagę udziału jednego z dwóch wspomnianych wyżej współpracowników Bernatowicza - obcokrajowców obeznanych dobrze z rzeźbą czeską, silnie italianizującą i związaną z oprawą architektoniczna, mając na uwadze nie tylko wykonanie samej figury, lecz także ich udział w fazie projektowej.

Grono współpracowników Bernatowicza zasilał we wczesnym okresie twórczości Johann Georg Plersch (ok. 1700-1774), niewątpliwie najważniejsza osobistość wśród warszawskich rzeźbiarzy działających w okresie rządów dynastii saskiej ${ }^{38}$. Od około $1735 \mathrm{r}$. szef wielkiego warsztatu o rozmiarach wręcz przedsiębiorstwa rzeźbiarskiego, wyspecjalizowany we wszelkich technikach, był w plejadzie licznych rzeźbiarzy warszawskich okresu saskiego niewątpliwie artystą najbardziej twórczym i utalentowanym. Do dziś ma on też spośród stołecznych rzeźbiarzy okresu późnego baroku najliczniej zachowany dorobek. Od 1735 r. Plersch nosił tytuł Hofbildhauera - nadwornego rzeźbiarza Augusta III. Dzięki temu stanowisku i wiążącym się z nim kontaktom z establishmentem dworskim i magnackim mógł rozwinąć oszałamiającą karierę, nieosiagalną dla innych mistrzów dłuta w Warszawie. Jego udziałem była zewnętrzna i wewnętrzna dekoracja rzeźbiarska pierwszych gmachów stolicy: Zamku Królewskiego, pałacu Saskiego, znacznej części nowo powstałych i modernizowanych starszych pałaców magnackich, założeń ogrodo-

\footnotetext{
${ }^{37}$ Jakub SITO, „Bay (Bai, Baia, Baio, Bay, Baya) Carlo Antonio Maria (Karol Antoni)”, [w:] Słownik architektów i budowniczych środowiska warszawskiego XV-XVIII wieku, red. Paweł MIGASIEWICZ, Hanna OSIECKA-SAMSONOWICZ, Jakub SITO, Warszawa 2016, s. 37-45.

${ }^{38}$ Katarzyna MIKOCKA-RACHUBOWA, „Plersch Johann Georg”, [w:] Słownik artystów polskich i obcych w Polsce działajacych (zmarlych przed 1966 r.). Malarze, rzeźbiarze, graficy, t. VIII, Warszawa 2003, s. 276-283; SITO, Wielkie warsztaty rzeźbiarskie..., s. 151-305 (tamże wcześniejsza literatura).
} 
wych czy kościołów. Pierwszoplanowa pozycja Plerscha łączyła się ze współpracą z najważniejszymi architektami warszawskimi epoki saskiej, głównie królewskimi. Byli nim początkowo Johann Sigmund Deybel (ok. 1700-1751) ${ }^{39}$ i Carl Friedrich Pöppelmann $(1696-1750)^{40}$ a od lat 40. Jakub Fontana $(1710-1773)^{41}$.

Dwaj pierwsi to twórcy najważniejszych dzieł stołecznej królewskiej i magnackiej architektury pałacowej 1. połowy XVIII w. Styl ich projektów bliski estetyce francuskiego klasycyzmu i wczesnego rokoka cechowała wstrzemięźliwość i pewien rygoryzm, a zarazem delikatność. Budowle o klarownej dyspozycji i podziałach, z rozległymi, gładkimi, bezporządkowymi elewacjami, opięte były systemem delikatnych lizen bądź bonii w wielkim porządku i towarzyszących im płycin. Ważna rola przypadała wysokim, fantazyjnie komponowanym dachom i hełmom. Sylwetowy efekt pałaców Deybla i Pöppelmanna współtworzyła starannie aranżowana, oszczędna, ale wysmakowana dekoracja rzeźbiarska. Akcenty rzeźbiarskie skupiały się w centralnych węzłach kompozycyjnych - na dachach mansardowych, attykach pełnych bądź balustradowych, z szeregiem posagów lub grupami rzeźbiarskimi, na schodach zewnętrznych, założeniach bramnych i parkanach. Plersch, wykształcony głównie na wzorach rzymskiej i praskiej rzeźby barokowej, a więc w kręgu tradycji zupełnie odmiennej, szybko zaadaptował się do potrzeb reprezentacji wyrażanych w pałacowej architekturze stolicy i w kręgu jej oddziaływania.

Z Carlem Friedrichem Pöppelmannem po raz pierwszy zetknął się Plersch w 1726 r. w związku z budową na rozkaz Augusta II pałacu Błękitnego, przeznaczonego dla naturalnej córki króla Anny Orzelskiej ${ }^{42}$. Pośpiech, z jakim dokonywano tej inwestycji, i niedostatek własnych artystów kazał szukać królowi pomocy u Elżbiety Sieniawskiej. Z misją wyszukania rzeźbiarza (a także sztukatora) oddelegowany został właśnie młody Pöppelmann, od dwóch lat przebywający w Polsce. Z nielicznie zachowanych archiwaliów wiadomo, że przy pałacu Błękitnym zatrudnionych było aż trzech architektów: obok Pöppelmanna także Joachim Daniel Jauch jako szef królewskiego Bauamtu oraz Johann Sigmund Deybel ${ }^{43}$. Podział kompetencji pozostaje w przypadku tej „fabryki” nie całkiem jasny, wydaje się jednak, iż pierwsze słowo należało do Deybla, będącego wówczas głównym architektem królewskim, i że to spod jego ręki wyszły projekty tympanonów oraz portali, realizowanych, jak można się domyślać, przez Plerscha.

Warszawski rzeźbiarz niedługo potem pracował przy Deyblowskich wnętrzach pałacu wilanowskiego, pozostającego od 1730 r. w rękach Augusta II (ściśle według dyspozycji Deybla i we współpracy z Martinem Schnellem, królewskim lakiernikiem, wykonał słynny Gabinet Chiński ${ }^{44}$ ). Był następnie głównym rzeźbiarzem pozostającym w dyspozycji Deybla przy jego najważniejszych dziełach przełomu lat 20. i 30. - pałacu Jana Fryderyka Sapie-

\footnotetext{
39 Jakub SITO, „Deybel (Teubel, Teuble, Teubler, Deibler) Johann Sigmund (Jan Zygmunt) von Hammerau”, [w:] Stownik architektów i budowniczych..., s. 115-124.

40 Jakub SITO, „Pöppelmann Carl Friedrich von”, [w:] Słownik architektów i budowniczych ..., s. 361-368.

${ }^{41}$ BARTCZAKOWA, Jakub Fontana ..., passim; Monika WYSZOMIRSKA, „Fontana (Fontanna, Fontani) Jakub (Giacomo)", [w:] Słownik architektów i budowniczych..., s. 137-150.

42 Walter HENTSCHEL, „Pałac Błękitny w Warszawie”, Biuletyn Historii Sztuki, XXVI: 1964, nr 4, s. 252-265; Andrzej ROTTERMUND, Pałac Błękitny, Warszawa 1970, passim; SITO, Wielkie warsztaty rzeźbiarskie..., s. 245-265; id., ,Sculptors from the Court Circles of Augustus II the Strong and Augustus III, Kings of Poland and Electors of Saxony", [w:] Poland and Artistic Culture of Western Europe 14 th-20 th Centuries, red. Barbara PRZYBYSZEWSKAJARMIŃSKA, Lech SOKÓŁ, Warszawa 2014, s. 199-262.

${ }^{43}$ HENTSCHEL, „Pałac Błękitny...”, s. 252-265.

44 Jakub SITO, „Nieznane «varsaviana» w twórczości Martina Schnella, nadwornego lakiernika królewskiego”, Studia Wilanowskie, 2011, t. XVIII, s. 140-151.
} 
hy przy Zakroczymskiej oraz rezydencji Poniatowskich w Wołczynie wraz z tamtejszym kościołem dworskim.

O ile z Deyblem przyszło (niezbyt zresztą długo) pracować Plerschowi w pierwszej mierze dla magnaterii, o tyle z Carlem Friedrichem Pöppelmannem, głównym architektem saskim w Polsce, współtworzył on przede wszystkim budowle królewskie. Współpraca z tym ostatnim, choć anonsowała się już wcześniej, nasiliła się szczególnie od około 1735 r., kiedy Plersch objął stanowisko pierwszego rzeźbiarza nadwornego i przystapił do królewskiego Bauamtu ${ }^{45}$.

Do większości inwestycji warszawskich projektowanych przez Pöppelmanna młodszego zachowało się szczęśliwie sporo rysunków zarówno autorskich, jak i powstałych w Baubüro architekta ${ }^{46}$, rozrysów realizacyjnych i kopii wykonywanych przez kreślarzy Bauamtu. Liczne rysunki elewacji uwzględniały dekorację rzeźbiarską. Zachowało się też kilka plansz (głównie kaplicy pałacu Saskiego) poświęconych niemal wyłącznie rzeźbie. Czasami jako jej realizator przewidziany był z urzędu Johann Georg Plersch ze swym królewskim warsztatem, co wyraźnie potwierdzają źródła archiwalne. Niekiedy zachowanym rysunkom odpowiadają dzieła zrealizowane, istniejące bądź znane jedynie $\mathrm{z}$ fotografii. Prześledzenie poszczególnych inwestycji pod kątem porównania rysunków z realizacją przedstawia się szczególnie ciekawie. Na większą skalę, ze względu na zachowaną spuściznę, jest to zresztą możliwe jedynie w przypadku współpracy Plerscha z Pöppelmannem do śmierci tego ostatniego w $1750 \mathrm{r}$.

O ile przy pałacu Błękitnym Pöppelmann odgrywał raczej rolę pomocniczą, bliższą funkcji konduktora budowy, to już wkrótce potem będzie pełnił rolę pierwszoplanowego architekta królewskiego. Z 2. połowy roku 1734 pochodzi właśnie jego autorstwa tzw. VIII projekt nowego okazałego pałacu Saskiego przeznaczonego dla Augusta III $^{47}$. W odróżnieniu od poprzednich, fantastycznych projektów przeznaczonych dla Augusta Mocnego, ten miał pewną szansę na realizację ${ }^{48}$, do której jednak nigdy nie doszło. Wykonawcą bogatej dekoracji rzeźbiarskiej niemal na pewno miał być starający się już wówczas o stanowisko pierwszego rzeźbiarza Plersch. Wytworny pałac, o ramowej artykulacji i gładkim licu ścian, miał zgodnie z francusko-saskim modusem rygorystycznie rozłożone akcenty rzeźbiarskie: plastyczne wypełnienia tympanonów z fantazyjnymi, asymetrycznymi kartuszami heraldycznymi w towarzystwie bóstw kobiecych, Fam i rozłożystych pęków panopliów, figury kobiece zdobiące parami naroża ryzalitów frontowych czy sfinksy ujeżdżane przez putta przed głównym wejściem (il. 4). Co niezwykle ciekawe, rzeźby te zostały narysowane przez Pöppelmanna niejako z uwzględnieniem dynamicznej maniery rzeźbiarskiej Plerscha, o charakterystycznej skręconej, tanecznej sylwecie i skomplikowanym, zygzakowatym rzucie draperii z mięsistą przewiązką w partii bioder. Dodajmy, że żaden z saskich rzeźbiarzy pozostających w dyspozycji króla w Dreźnie i Warszawie, bez reszty posługujących się chłodnym francusko-klasycznym stylem, nie mógłby wchodzić tu w gre jako wykonawca. Partie rzeźbiarskie rysunku powstały tedy ewidentnie ,,pod dłuto" Plerscha ${ }^{49}$.

\footnotetext{
45 Walter HENTSCHEL, Die Sächsische Baukunst des 18. Jahrhunderts in Polen, Berlin 1967, s. 23, 447; SITO, Wielkie warsztaty rzeźbiarskie..., s. 175.

${ }^{46}$ HENTSCHEL, Die Sächsische Baukunst..., s. 59-68.

${ }^{47}$ Ibid., s. 156-161; SITO, Wielkie warsztaty rzeźbiarskie..., s. 250.

48 SITO, Wielkie warsztaty rzeźbiarskie..., s. 250.

${ }^{49}$ Ibid., s. 250.
} 


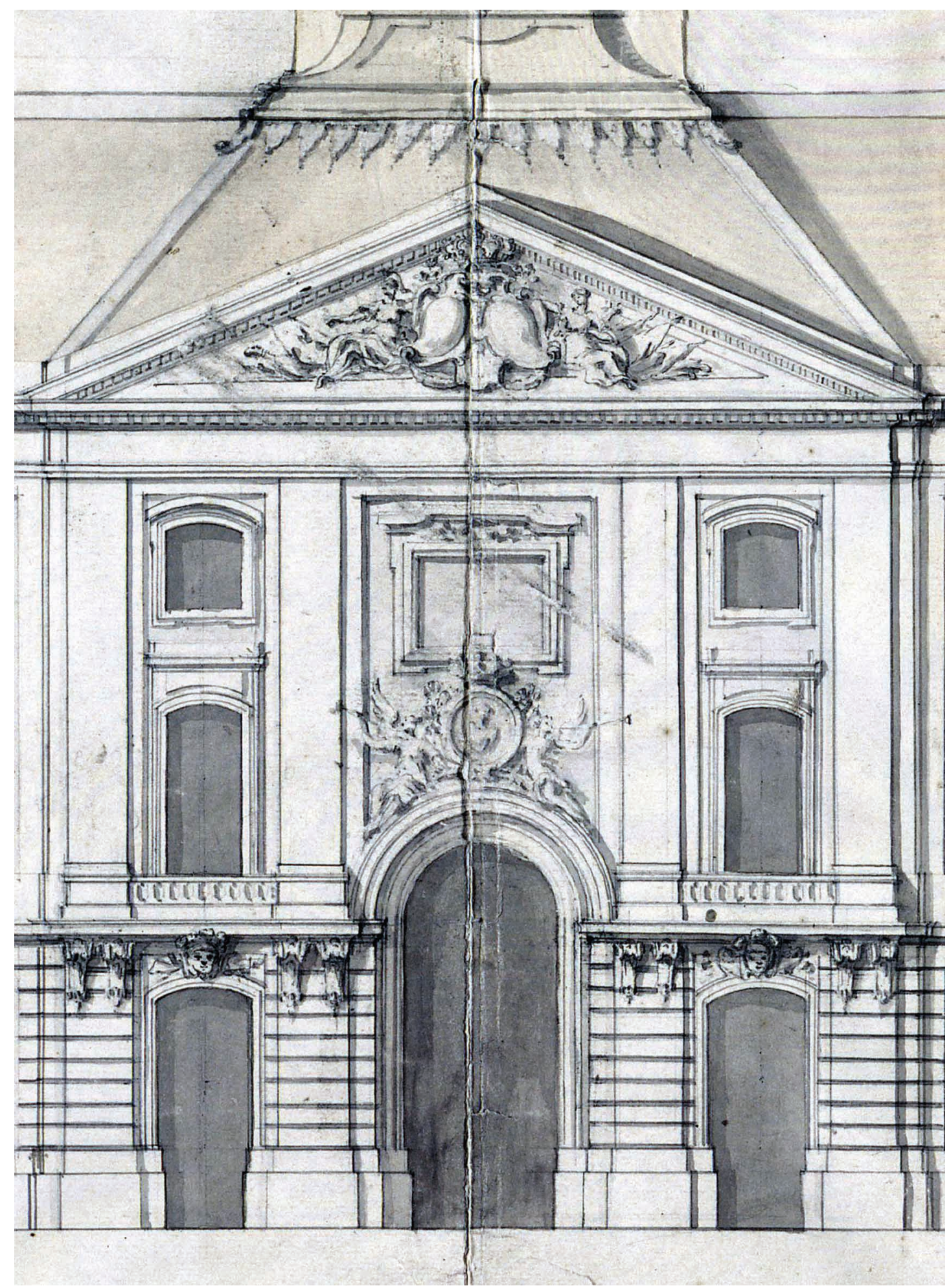

4. Carl Friedrich Pöppelmann, tzw. VIII projekt elewacji frontowej nowego pałacu Saskiego, ryzalit środkowy, ok. 1734,

Drezno, Sächsisches Hauptstaatsarchiv, S.VII, F. 89, Nr.1 A, oo. Fot. Piotr Eugowski 
Czas najintensywniejszej współpracy obu artystów przypadł na lata budowy i rozbudowy trzech wielkich rezydencji królewskich: Zamku Warszawskiego (1739-1752) ${ }^{50}$, Nowego Zamku w Grodnie (1738-1742) ${ }^{51}$ i Założenia Saskiego (ok. 1740-1750) ${ }^{52}$. W każdym z tych przypadków niezwykle istotne dla efektu artystycznego dzieła było porozumienie między architektem-projektantem a warsztatem rzeźbiarskim. I tak, na rysunku Pöppelmanna dla Zamku Warszawskiego czytelna jest ikonografia rzeźb projektowanych do wykonania przez Plerscha, ich sylweta, a nawet głębokość modelunku zaznaczana cieniowaniem. Można też w nim dostrzec (tak jak w omówionym VIII projekcie na nowy pałac Saski) respekt wobec indywidualnej maniery rzeźbiarza, który je wykona, a tym najwyraźniej od początku miał być Plersch. Pewne partie (np. kartusz z trofeami) były co do ostatniego szczegółu uzgodnione jeszcze w fazie powstawania projektu, kształt innych (np. posagów Polonii i Lituanii) musiał być dyskutowany, albowiem między rysunkiem a realizacją widoczne są pewne różnice. Nawet one nie zacierają jednak generalnej zgodności wizji Pöppelmanna z późniejszym efektem pracy Plerscha ${ }^{53}$.

Wydaje się, że najbardziej spektakularna i owocna była jednak współpraca Johanna Georga Plerscha z wybitnym warszawskim architektem pochodzenia włoskiego - Jakubem Fontaną (1710-1773) 54 . Ten ostatni zyska w nieodległej przyszłości sławę ,,pryncypalnego w kraju naszym architekta” czy ,,pierwszego w kraju naszym wszystkich zdaniem architekta", a jego domeną będą zarówno projekty budowli monumentalnych, jak i dzieła wystroju architektoniczno-rzeźbiarskiego ${ }^{55}$. Z warszawskich dzieł architektury zaprojektowanych przez Fontanę i zdobionych przez Plerscha wyróżniają się spektakularna rozbudowa pałacu Bielińskich (ok. 1744-1755) ${ }^{56}$, fasada kościoła Św. Krzyża wraz ze wspaniałym podjazdem dla karet (projekt 1745 , realizacja do 1760$)^{57}$, rokokowe partie fasady i wnętrze kościoła Wizytek (ok. 1755-1762) ${ }^{58}$, wreszcie wnętrze nowej Izby Poselskiej na Zamku Warszawskim $(1762-1763)^{59}$. Za wysoce prawdopodobny można przyjać

\footnotetext{
${ }^{50}$ HENTSCHEL, Die Sächsische Baukunst..., s. 297-307; Jerzy LILEYKO, Zamek Warszawski. Rezydencja królewska i siedziba władz Rzeczypospolitej 1569-1763, Wrocław-Warszawa-Kraków-Gdańsk-Łódź 1984, s. 231-245, 260-269; SITO, Wielkie warsztaty rzeźbiarskie..., s. 175-185, 250-252.

${ }^{51}$ HENTSCHEL, Die Sächsische Baukunst..., s. 285-297; SITO, Wielkie warsztaty rzeźbiarskie..., s. 252-254.

${ }^{52}$ HENTSCHEL, Die Sächsische Baukunst..., s. 263-285; SITO, Wielkie warsztaty rzeźbiarskie..., s. 185-196, 255-264.

${ }^{53}$ SITO, Wielkie warsztaty rzeźbiarskie..., s. 247-252.

${ }^{54}$ BARTCZAKOWA, Jakub Fontana..., s. 34-35, 101-112; SITO, Wielkie warsztaty rzeźbiarskie..., s. 265-301; WYSZOMIRSKA, op. cit., s. 137-150.

${ }^{55}$ Wojciech. BOBERSKI, „Splendor architekta. O «mediach sławy» w czasach nowożytnych”, [w:] Architekt-budowniczy-mistrz murarski. Materiały z sesji naukowej IS PAN, Warszawa 24-25 listopada 2004 roku, red. Hanna FARYNAPASZKIEWICZ, Małgorzata OMILANOWSKA, Jakub SITO, Warszawa 2007, s. 25-46.

${ }^{56}$ Jolanta PUTKOWSKA, „Warszawski zespół rezydencjonalny Franciszka Bielińskiego Marszałka Wielkiego Koronnego", Kwartalnik Architektury i Urbanistyki, XLI: 1996, nr 1, s. 17-46; SITO, Wielkie warsztaty rzézbiarskie..., s. $277-$ 281.

${ }^{57}$ BARTCZAKOWA, Jakub Fontana..., s. 160-169; Elżbieta KOWALCZYKOWA, „Kościół Św. Krzyża w Warszawie. Monografia architektoniczna”, Rocznik Warszawski, 1971, t. X s. 5-46; Mariusz KARPOWICZ, „Wartości artystyczne kościoła Św. Krzyża”, [w:] Ksiega Pamiqtkowa. Kościót Św. Krzyża w Warszawie w trzechsetna rocznice konsekracji 1696-1996, red. Tomasz CHACHULSKI, Warszawa 1996, s. 143-156; Jakub SITO, „Historia fundacji i budowy kościoła Św. Krzyża”, [w:] Serce Miasta..., 146-153.

${ }^{58}$ Janina M. KRASZEWSKA, „Materiały do historii budowy kościoła Wizytek”, Biuletyn Historii Sztuki i Kultury, 1937, t. V, s. 313-340; Stanisław LORENTZ, „Architekt PP. Wizytek z lat 1754-62”, Biuletyn Historii Sztuki, XXI: 1959, nr 3-4, s. 376-383; Jakub SITO, „Ołtarz główny warszawskiego kościoła PP. Wizytek. Projekt, realizacja, treści ideowe”, Rocznik Warszawski, 2005, t. XXXIII, 2005, s. 151-164; Maria CHODYKO, Karol GUTTMEJER, Jakub SITO, Kościót wizytek w Warszawie, Warszawa 2006.

${ }^{59}$ BARTCZAKOWA, Jakub Fontana ..., s. 210-213; Jakub POKORA, „«Ja, mądrość mieszkam w radzie». Izba Poselska
} 
udział Plerscha w planowanej budowie fasady pijarskiego Collegium Nobilium (projekt Jakuba Fontany z lat 1742-1743) ${ }^{60}$. Z zakresu małej architektury do najważniejszych wspólnych prac Fontany jako architekta i Plerscha jako rzeźbiarza zaliczają się para ołtarzy przytęczowych kościoła Pijarów w Łowiczu (1744-1745), nagrobek Mniszchów w kościele Reformatów (po 1747) ${ }^{61}$, ołtarz główny w kościele Karmelitów Bosych $(1749)^{62}$, nagrobek Jana Tarły w kościele Jezuitów (1751-1753) ${ }^{63}$ oraz ołtarz główny kościoła Wizytek (1758-1760) ${ }^{64}$.

Z rodziną Fontanów młody rzeźbiarz związał się w styczniu 1729 r. przez ożenek z Marianną Magdaleną, siostrą Jakuba. Plersch znał się w czasach swej młodości z ich ojcem Giuseppe Fontaną, kiedy w latach 20. obaj pracowali dla hetmanowej Elżbiety Sieniawskiej przy jej inwestycjach w rezydencji wilanowskiej ${ }^{65}$. Kiedy Plersch żenił się z Magdaleną Fontanówną, Jakub miał dopiero 19 lat. Szwagier przyszłego architekta królewskiego był więc starszy i bardziej doświadczony, miał „europejskie obycie” - znajomość sztuki Rzymu i Pragi. Nie pozostało to bez pewnego wpływu na ich późniejszą współpracę i cechujące ją niemal partnerskie stosunki, nie tak znów częste w relacjach architekt - rzeźbiarz w epoce nowożytnej. Około roku 1730 Plersch miał już własny warsztat, wykonywał prestiżowe zamówienia, w tym królewskie, podczas gdy Jakub Fontana dopiero terminował najpierw pod kierunkiem ojca, a następnie $u$ innych aktywnych w Warszawie architektów, głównie u Carla Antonia Baya ${ }^{66}$. W 2. połowie 1731 r. Jakub udał się na swego rodzaju edukacyjną Grand Tour do Francji i Włoch, gdzie pozostawał przypuszczalnie do początku $1733 \mathrm{r} .{ }^{67}$ Tam też jego sztuka nabrała europejskiego poloru. W Paryżu chłonął zarówno tradycję klasyczną, fundamentalną dla kultury artystycznej Francji, jak i wszelkie nowinki doby rokoka, której apogeum przypadło właśnie na lata 30. XVIII w. Jest bardzo prawdopodobne, że zetknął się bezpośrednio z Juste-Aurelle Meissonierem, być może nawet uczył się u niego, czy raczej praktykował w jego studio ${ }^{68}$. Co do pobytu włoskiego, to można mniemać, że młody Fontana niemal z całą pewnością przebywał w Wiecznym Mieście, gdzie miał szansę ugruntować rzymskie pryncypia architektury, z jakimi zetknął się już w Warszawie, oraz odbyć solidne studia nad rzymską tradycją architektoniczną 2. połowy XVII i początku XVIII w. ${ }^{69}$ Poznał niewątpliwe dzieła Gianlorenza Berniniego i jego naśladowców, Francesca Borrominiego, a także Carla

na Zamku Królewskim w Warszawie”, [w:] Arx felicitatis. Księga ku czci profesora Andrzeja Rottermunda, Warszawa 2001, s. 373-381.

${ }^{60}$ Ryszard M. MĄCZYŃSKI, Pijarski pałac Collegium Nobilium w Warszawie, Warszawa 1996; SITO, Wielkie warsztaty rzeźbiarskie..., s. 285-287.

61 Jacek GAJEWSKI, „Nagrobek Jana Tarły w Warszawie i zagadnienia jego rekonstrukcji (mała architektura w twórczości Jakuba Fontany; Plersch i warsztat)”, Arteria. Rocznik Wydziału Sztuki Politechniki Radomskiej, 2012, t. 10, s. 58-91; SITO, Wielkie warsztaty rzeźbiarskie..., s. 205-206.

${ }^{62}$ SITO, Wielkie warsztaty rzeźbiarskie..., s. 210-213.

${ }^{63}$ Zygmunt BATOWSKI, „Pomnik Tarły w kościele jezuickim w Warszawie i jego twórca. Przyczynek do dziejów rzeźby w Polsce w XVIII wieku”, Sprawozdania z Posiedzeń Towarzystwa Naukowego Warszawskiego, Wydz. II, 1933, t. XXVI, s. 43-59; Ryszard MĄCZYŃSKI, Zespoły architektoniczne Collegium Regium i Collegium Nobilium warszawskich pijarów 1642-1834, Warszawa 2010, s. 170-176; GAJEWSKI, „Nagrobek Jana Tarły w Warszawie...”, s. 5891; SITO, Wielkie warsztaty rzeźbiarskie..., s. 213-217.

${ }^{64}$ SITO, „Ołtarz główny...”, s. 151-164.

${ }^{65}$ BATOWSKI, op. cit., s. 6; SITO, Wielkie warsztaty rzébiarskie..., s. 265

${ }^{66}$ BARTCZAKOWA, Jakub Fontana..., s. 13-37; WYSZOMIRSKA, op. cit., s. 137-150.

${ }^{67}$ GAJEWSKI, „Nagrobek Jana Tarły...”, s. 89-91; SITO, Wielkie warsztaty rzézbiarskie..., s. 266-267.

${ }^{68}$ GAJEWSKI, „Nagrobek Jana Tarły...”, s. 89-91; SITO, Wielkie warsztaty rzeźbiarskie..., s. 267-269.

${ }^{69}$ BARTCZAKOWA, Jakub Fontana ..., s. 19; SITO, Wielkie warsztaty rzeźbiarskie..., s. 269-274. 
Rainaldiego i Pietra da Cortony. Spośród architektów działających na przełomie XVII i XVIII w. najbliżsi byli mu Carlo Fontana, a także Andrea Pozzo ${ }^{70}$. Jest oczywiste, że u progu 4. dekady XVIII w., kiedy w Rzymie budowano już niewiele, a podziwem ówczesnych teoretyków i praktyków architektury cieszyły się przede wszystkim projekty z czasów „heroicznego” okresu, uwaga adepta architektury przybyłego wówczas nad Tybr siłą rzeczy musiała się zwracać ku architektonicznej tradycji, ku wielkiej przeszłości Rzymu.

Z tradycji architektonicznej Wiecznego Miasta Fontana przejął predylekcję dla architektury porządkowej, zwłaszcza kolumnowej, w tym efektownych rozwiązań perspektywicznych, dla bogactwa i malowniczości, zawsze jednak moderowanych przez tradycję akademicko-klasyczną. W projektach małej architektury, jakie tworzył razem z Plerschem, z Rzymu, zwłaszcza ze sztuki Borrominiego, wywodzi się komplikacja konstrukcji (np. wzajemne przenikanie się struktur architektonicznych), światłocieniowość i ożywienie detalu, z drugiej zaś strony - eksponowanie głównych elementów porządkowych i skłonność do integracji z zastanym wnętrzem (w duchu np. Carla Fontany).

Włoska i francuska podróż przyczyniła się do wykształcenia przez Fontanę własnego stylu, łączącego elementy włoskiego dojrzałego i późnego baroku oraz francuskiego rokoka, z pobrzmiewającym stale umiarkowanym komponentem klasycznym. Styl ów w znacznym stopniu odpowiadał formacji i wrażliwości stałego współpracownika architekta, którym od lat 40. XVIII w. stał się Johann Georg Plersch. Obu łączyło wykształcenie rzymskie, estyma dla tradycji sztuki Seicenta, zwłaszcza w ruchliwym, ekspresyjnym wydaniu 2. połowy XVII w. Obaj równie chętnie odwoływali się do Berniniego i jego naśladowców. Plersch pozostawał przy tym może mniej skłonny do klasycyzacji, ale umiał się nagiąc $\mathrm{w}$ tym względzie do wymagań zleceniodawców i architekta. U obu artystów niezwykle ciekawie wygląda pierwiastek rokokowy z jego malowniczością i fantazją. Fontana wprowadzał tu nowatorski element francuski znany mu z autopsji (zwłaszcza poprzez lekcję Meissoniera) i czerpany z modnych wzorników graficznych. Plersch nie znał wprawdzie rzeźby i ornamentyki francuskiej, ale był na nią niejako „przygotowany” poprzez znajomość zarówno ekspresyjnej rzeźby praskiej, jak i malowniczej tradycji rzymskiej plastyki 2. połowy XVII i początku XVIII w. Czynniki te wykazywały zaskakującą zgodność z propozycjami wprowadzanymi przez rokoko francuskie, zwłaszcza w jego radykalnym wydaniu, jakie najsilniej wpłynęło na Jakuba Fontanę. Być może nie jest przypadkiem, że wypracowanie owych wzorów, dokonane we Francji w latach 20. odbyło się w oparciu o transfer późnobarokowych wzorów włoskich. Nie sposób pominąć tu choćby jednego z czołowych dzieł ilustrowanych, które zainicjowało rozwój radykalnego rokoka francuskiego - Gillesa-Marie Oppenorda Livre de fragments d'architectures, recüeilis et dessinés à Rome d'après les plus beaux monuments (przed 1723), prezentującego co bardziej ekscentryczne pomysły architektoniczno-rzeźbiarskie XVII-wiecznego Rzymu w wydaniu już specyficznie francuskim, widocznym choćby w kadrowaniu, w kresce czy interpretacji reliefu ${ }^{71}$.

We współpracy Fontany i Plerscha przy wszystkich wymienionych wyżej dziełach nie zawsze można wyraźnie oddzielić wkład koncepcyjny rzeźbiarza i architekta. Wiadomo na przykład, że Franciszkowi Bielińskiemu, marszałkowi koronnemu i szefowi Komisji Brukowej, Jakub Fontana przekazał w roku 1752 zachowany rysunkowy projekt pomnika

\footnotetext{
70 Jacek GAJEWSKI, „Sztuka w prymasowskim Łowiczu”, [w:] Łowicz. Dzieje miasta, red. Ryszard KOŁODZIEJCZYK, Warszawa 1986, s. 544-551, 572-579; Jerzy KOWALCZYK, „Rola Rzymu w późnobarokowej architekturze polskiej”, Rocznik Historii Sztuki, XX: 1994, s. 222, 286, 290; SITO, Wielkie warsztaty rzé́biarskie..., s. 269-274. 71 Jean-François BÉDARD, Decorative Games. Ornament, Rhetoric, and Noble Culture in the Work of Gilles-Marie Oppenord (1672-1742), Lanham, MD 2011.
} 


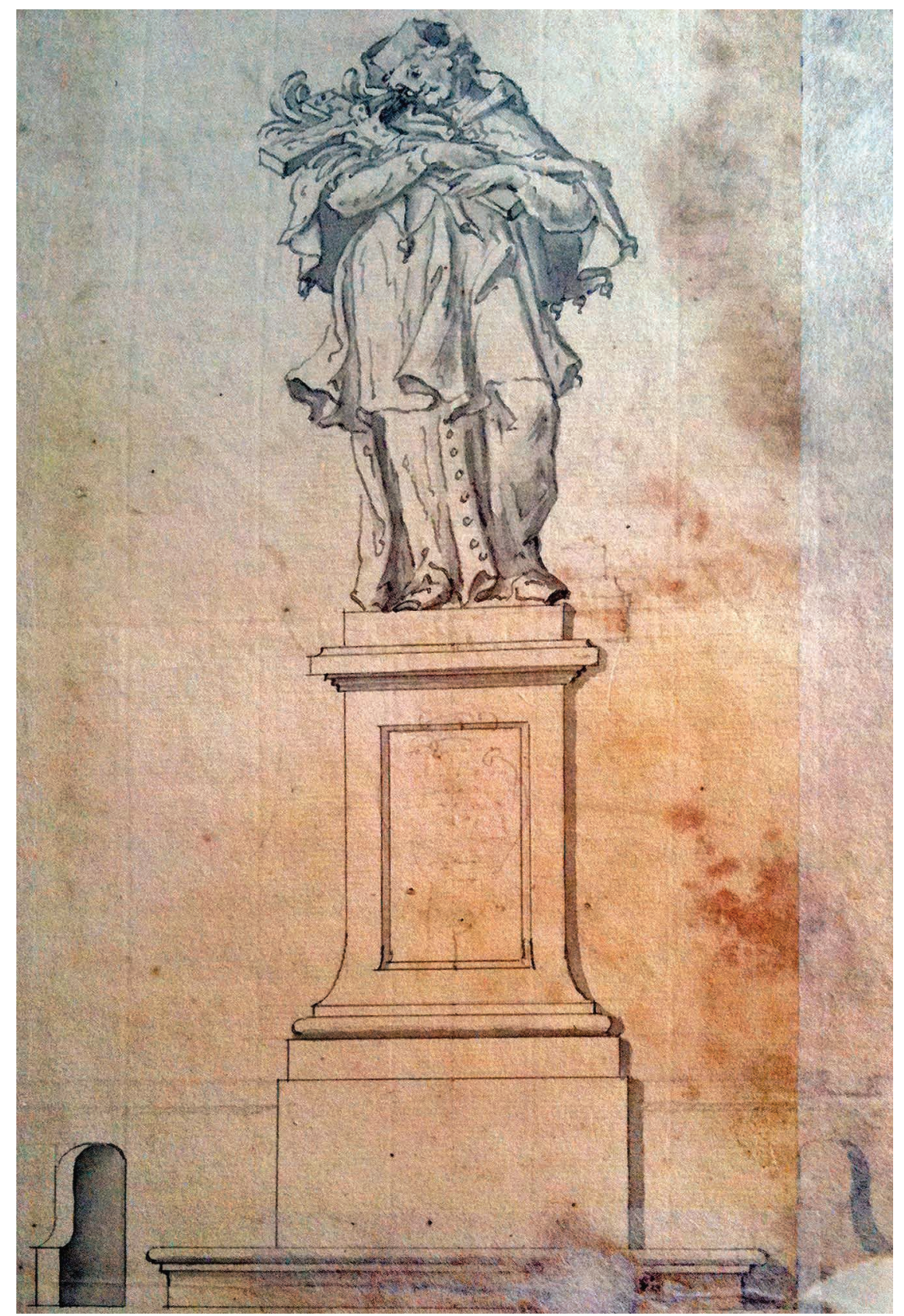

5. Johann Georg Plersch (wg koncepcji Jakuba Fontany?), projekt pomnika św. Jana Nepomucena na placu Trzech Krzyży w Warszawie, 1752, Warszawa, Archiwum Gtówne Akt Dawnych, Archiwum Komierowskich 9/9, k. 35. Fot. Jakub Sito.

św. Jana Nepomucena przy placu Trzech Krzyży, który miał koronować ważny etap prac drogowych w Warszawie (il. 5). Zgodnie z pisemną informacją Fontany na odwrocie rysunku ,według tego abrysu obliguje się IP Plersz zgotować statuę [...] pro ultimi Augusti roku 1752, za który to roboty maiąc Komiss od Jaśnie Wielmożnego Imci Pana Bielińskiego Marszałka WK deklaruje temu Imc Panu Plerschowi"72. Trudno powiedzieć, czy

\footnotetext{
72 Jakub SITO, „Rzeźba św. Jana Nepomucena - pamiątka po działalności Komisji Brukowej”, Spotkania z Zabytkami,
} 2016, nr 12, s. 36-40. 


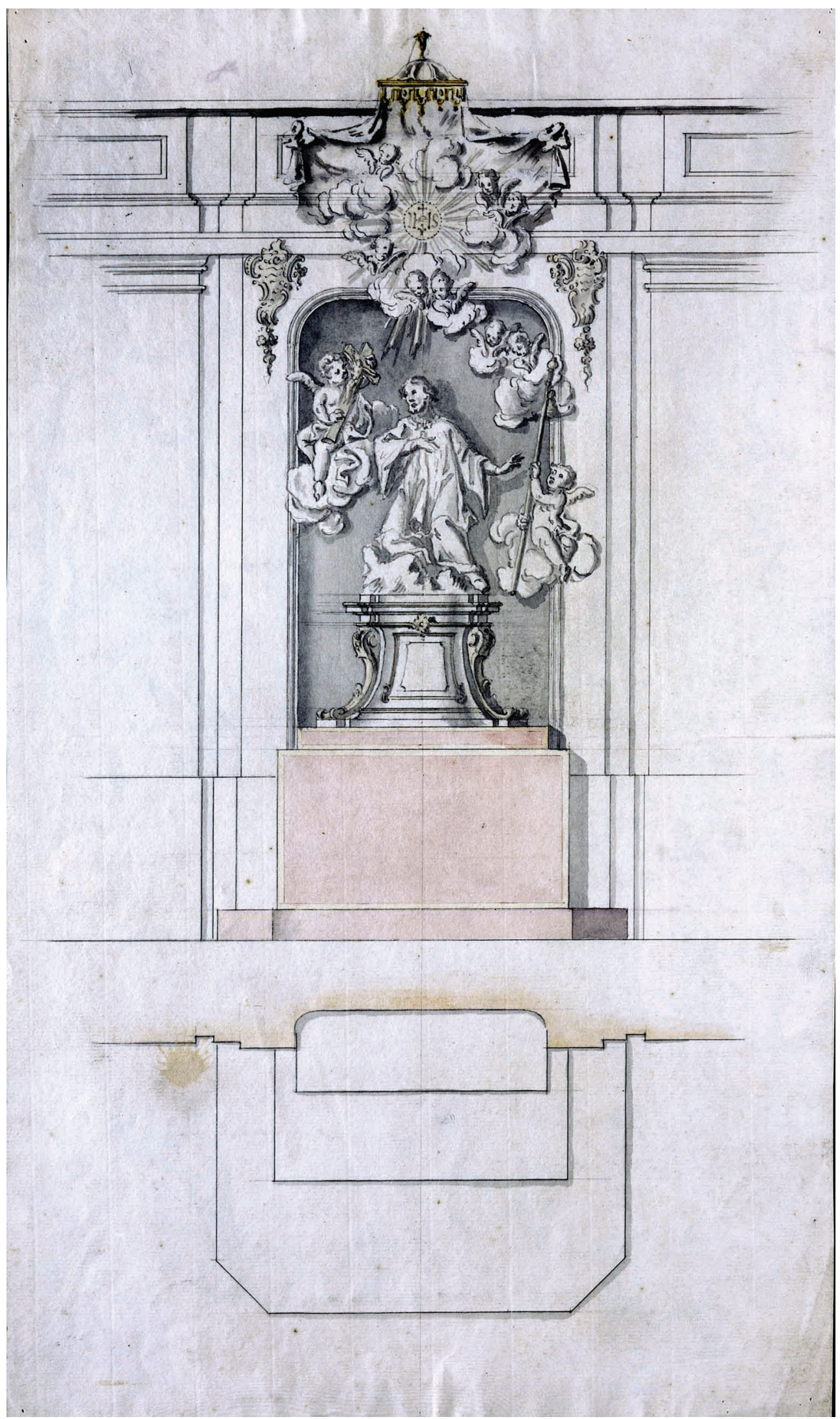

6. Johann Georg Plersch we wspótpracy z Carlem Friedrichem Pöppelmannem, projekt oltarza św. Anny w kaplicy pałacu Saskiego w Warszawie, ok. 1744, Drezno, Sächsisches Hauptstaatsarchiv, S.VII, F. 89, Nr.5 z. Fot. Sächsisches Hauptstaatsarchiv 


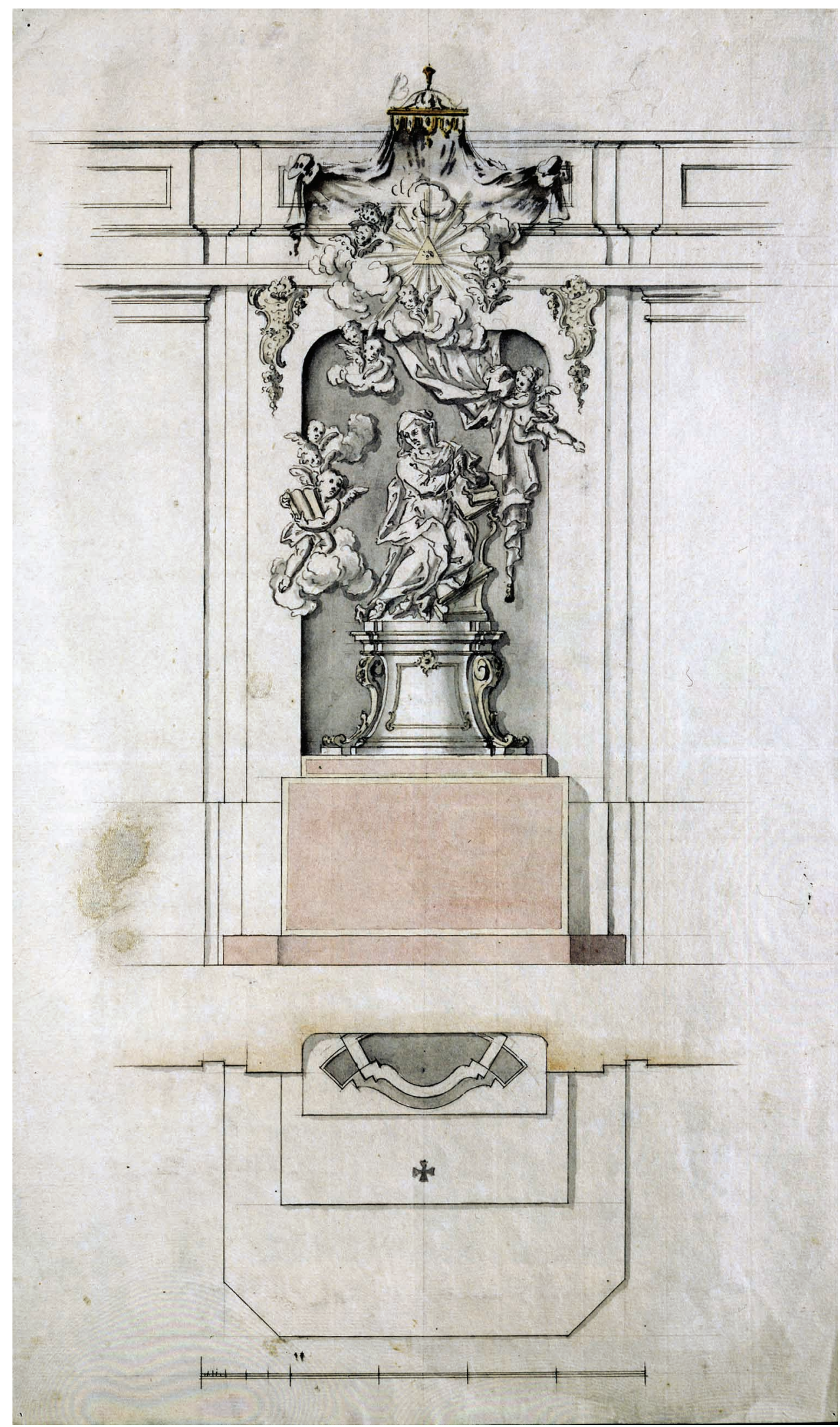

7. Johann Georg Plersch we wspótpracy z Carlem Friedrichem Pöppelmannem, projekt ołtarza św. Jana Nepomucena w kaplicy pałacu Saskiego w Warszawie, ok. 1744, Drezno, Sächsisches Hauptstaatsarchiv, S.VII, F. 89, Nr.5 y. Fot. Sächsisches Hauptstaatsarchiv 


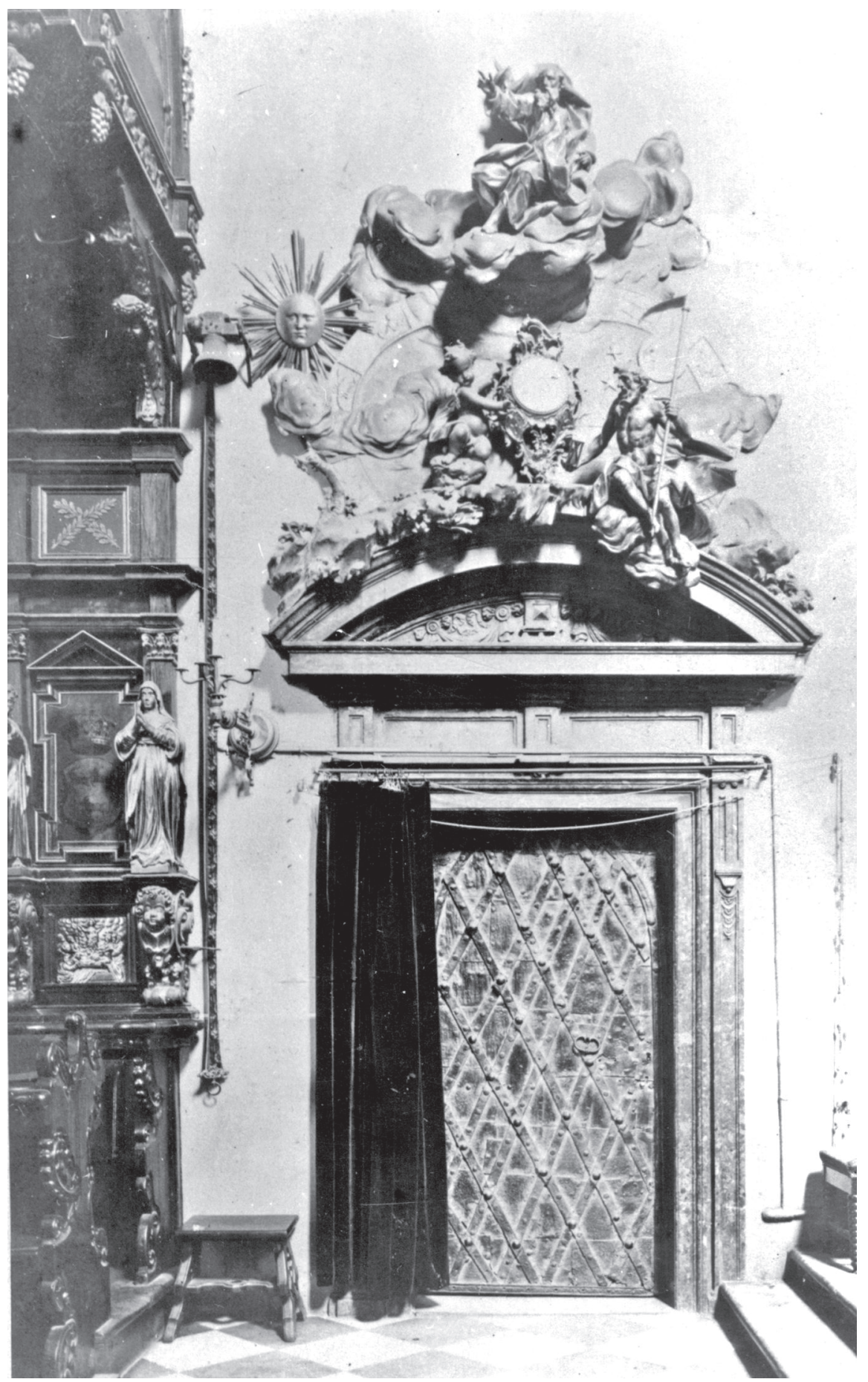

8. Johann Georg Plersch (projekt), Franz Anton Vogt (wykonanie), rzeźbiarska supraporta nad portalem do zakrystii w kolegiacie św. Jana w Warszawie, 1746. Fot. przed 1939, Warszawa, Instytut Sztuki PAN

ze strony Fontany było to jedynie pośrednictwo w zamówieniu złożonym u rzeźbiarza przez marszałka (określone jako „komiss od Jaśnie Wielmożnego Imci Pana Bielińskiego”), czy też uczestniczył on w projektowaniu. Sam rysunek - kompozycja, dukt kreski - nosi wszelkie cechy ręki Plerscha. Kształt cokołu, jedynego elementu, który można by wiązać z zakresem ścisłej kompetencji architekta - prostokątnego, rozszerzającego się lejkowato 
u podstawy, powtarza się także na innych rysunkach rzeźbiarza, np. w projektach rzeźb mitologicznych do Ogrodu Saskiego. W tym wypadku Plersch współpracował jednak nie z Fontana, a z Carlem Friedrichem Pöppelmannem. Elementy architektury umiejętnie przejęte z twórczości obu warszawskich architektów zawierają projektowane przez Plerscha ołtarze boczne Kaplicy Saskiej z roku 1744 (il. 6-7) ${ }^{73}$. Obok zaczerpniętych z prac Pöppelmanna prostokątnych obramień o zaokraglonych narożach Plersch zastosował formy typowe dla Jakuba Fontany, jakimi były trapezoidalne cokoły, gięte w płaszczyźnie pionowej i poziomej, mające swój precedens w powstałym zaledwie rok wcześniej Fontanowskim projekcie elewacji Collegium Nobilium (dekoracyjne nadbudowy ryzalitów).

Jako projektant sensu stricto Plersch wymieniany był w 1746 r. w opisach realizacji supraporty nad portalem do zakrystii w kolegiacie św. Jana (il. 8) czy na wykonywanych dla podskarbiego wielkiego koronnego Karola Józefa Sedlnickiego rysunkach projektowych ołtarza głównego kościoła Paulinów w Leśnej w $1748 \mathrm{r} .{ }^{74}$ Plerscha jako projektanta sugeruje również kontrakt na loże kościoła Św. Krzyża, a także sam kształt konstrukcji ich części środkowej opartej na wzorach środkowoeuropejskich (obcych Fontanie) ${ }^{75}$. Dość tajemniczo brzmią w rozważanym tu kontekście zapiski warszawskiej kroniki pijarskiej, określające kenotafium Tarły jako „wystawione znakomitą sztuką Pleysza według jego kunsztu"76 nie wspominające zaś nic o Fontanie jako architekcie. Czyżby i w przypadku tego znakomitego dzieła udział rzeźbiarza wykraczał poza etap czysto wykonawczy? Być może relacje tego wybitnego artysty $\mathrm{z}$ architektami były bardziej złożone, w większym stopniu partnerskie niż sugerowano w dotychczasowej literaturze. Czy nie ukazywano ich dotąd zbyt jednostronnie, w kategoriach projektanta sprawującego koncepcyjny dyktat i bezwzględnie mu podporządkowanego wykonawcy? Zwłaszcza w oczach Fontany Plersch musiał być przecież cennym współpracownikiem, choćby jako artysta starszy, o dłuższym stażu. Był przecież doświadczonym wieloletnim wykonawcą rzeźb zdobiących zamki w Warszawie i Grodnie, dzięki interwencjom Pöppelmanna obytym z wzorami najnowszej francuskiej mody, skądinąd tak bliskimi Fontanie.

Obok Johanna Georga Plerscha drugim z najbardziej płodnych rzeźbiarzy stołecznych okresu rokoka był Johann Chrisostom Redtler (Redler) ${ }^{77}$. Ten wszechstronny artysta, posługujący się zarówno kamieniem w najrozmaitszych gatunkach, stiukiem, jak i z rzadka drewnem pochodził z terenów monarchii habsburskiej, najpewniej z Austrii. Urodził się, jak można domniemywać, zapewne około 1710 r., do Polski został sprowadzony przed

\footnotetext{
${ }^{73}$ HENTSCHEL, Die Sächsische Baukunst..., s. 272; SITO, Wielkie warsztaty rzeźbiarskie..., s. 263-264.

${ }^{74}$ OLEŃSKA, Jan Klemens Branicki..., s. 113.

75 Jakub SITO, „Loże w prezbiterium i transepcie”, [w:] Serce Miasta..., s. 234-235.

${ }^{76}$ MĄCZYŃSKI, Zespoty architektoniczne Collegium Regium..., s. 114-115, 170-176.

77 BARTCZAKOWA, Jakub Fontana ..., s. 43, 76, 79, 80, 82, 87, 88, 104, 110, 114-116, 118, 144, 243, 262, 288; Jadwiga KACZMARZYK, Późnobarokowa i rokokowa rzeźba kamienna w Warszawie, praca doktorska w Instytucie Sztuki PAN, 1970; ead., „Warszawski ośrodek rzeźbiarski czasów saskich” [w:] Warszawa XVIII wieku, cz. 3, Warszawa 1975, s. 131, 132, 136, 139, 140, 144-145; Mariusz KARPOWICZ, Sztuka polska XVIII wieku, Warszawa 1985, s. 155-161; Jerzy KOWALCZYK, „L'antichità nell'arte tardobarocca in Polonia”, [w:] L'Eredità classica in Italia e Polonia nel Settecento, red. Joanna HÜBNER-WOJCIECHOWSKA, Wrocław-Warszawa-Kraków 1992, s. 206-209; Mariusz KARPOWICZ, „Il modello antico nell arte polacca”, [w:] ibid., s. 219; Katarzyna MIKOCKA-RACHUBOWA, „Redler Johann Chrysostomus”, [w:] Stownik artystów polskich ..., t. VIII, Warszawa 2007, s. 265-272; Krzysztof GOMBIN, Inicjatywy artystyczne Eustachego Potockiego, Lublin 2009, passim; OLEŃSKA, Jan Klemens Branicki..., passim, Jakub SITO, „Fenomen rzeźb Johanna Chrisostoma Redlera”, [w:] Radzyń Podlaski. Miasto i rezydencja, red. Dominika LESZCZYŃSKA, Grażyna MICHALSKA, Radzyń Podlaski 2011, s. 101-119; SITO, „Sculptors from the Court...", s. 199-262.
} 
rokiem 1737, kiedy to ożenił się. Znał doskonale sztukę Wiednia (czy szerzej Dolnej Austrii) oraz Moraw, przede wszystkim tamtejszą rzeźbę, ale także dzieła małej architektury, na co wskazuje jego późniejsza twórcza współpraca $\mathrm{z}$ architektami warszawskimi. Z lat swojej środkowoeuropejskiej edukacji rzeźbiarz wyniósł założenia artystyczne, którym pozostał wierny przez okres całej swej twórczości w Polsce. Redtlerowskie ujęcie figury ludzkiej: typologia kompozycji, zasób póz, sposób oddania ruchu, fizjonomii i szczegółowych rozwiązań rzeźbionych postaci wywodziła się z akademickiej rzeźby wiedeńskiej. Bliska była mu zwłaszcza twórczość działających w pierwszej tercji stulecia w Wiedniu i w kręgu oddziaływania stolicy najwybitniejszych rzeźbiarzy pracujących dla dworu i arystokracji, pochodzących zarówno z Włoch, jak Giovanni Giuliani i Lorenzo Mattielli, czy też z Niemiec, jak Peter Strudel i Johann Kracker ${ }^{78}$. Z Wiednia Redtler przejął w pierwszej kolejności predylekcję do techniki kamiennej, a dalej biegłość techniczną, perfekcyjne opanowanie anatomii, doskonałość konstrukcji przestrzennej figury i pewną skłonność do antykizacji, traktowanej jednak specyficznie, bo łączącej rys klasycyzującyz silnym elementem malowniczości ${ }^{79}$.

Najwięcej zawdzięczał Redtler słynnemu Lorenzo Mattiellemu, pochodzącemu z Vicenzy nadwornemu rzeźbiarzowi dworu cesarskiego ${ }^{80}$. Wilanowskie, białostockie i radzyńskie kompozycje grupujące personifikacje, bóstwa, putta w rozmaitych układach, dekoracje heraldyczne czy sceny z charakterystycznymi motywami animalistycznymi, jak skaczące jelenie czy konie, zawdzięczały najwięcej pałacowym dekoracjom z terenu Wiednia i okolic (także po morawskiej stronie granicy), autorstwa Mattiellego i jego olbrzymiej pracowni. Rozwiązania rzeźb i grup rzeźbiarskich Redtlera znajdują więc swoje pierwowzory w dekoracjach pałaców w Eckartsau i Ladendorff koło Wiednia, w Buchlovicach czy Valticach na Morawach. Postacie Herkulesów zarówno w zakresie koncepcji grupy z powtarzającym się motywem herosa w różnych zmaganiach, jak i w szczegółowych rozwiązaniach kompozycyjnych wywodzą się z Mattiellowskiej dekoracji barokowego skrzydła wiedeńskiego Hofburga.

Poza Mattiellim liczne analogie łączą kompozycje Redtlerowskie z dziełami innego Włocha decydującego o obliczu rzeźby wiedeńskiej - Giovanniego Giulianiego ${ }^{81}$. Jako przykład mogą posłużyć najsłynniejsze chyba wiedeńskie przedstawienia bawiących się

\footnotetext{
78 SCHIKOLA, „Wiener Plastik...”, s. 85-162.

${ }^{79}$ SITO, „Fenomen rzeźb...”, s. 102-103.

${ }^{80} \mathrm{Z}$ ważniejszych pozycji bibliograficznych na temat Mattiellego należy wymienić: Ingeborg SCHEMPER-SPARHOLZ, „Skulptur und dekorative Plastik zur Zeit des Prinzen Eugen”, [w:] Prinz Eugen und das barocke Österreich, red. Karl GUTKAS, Wien 1985, s. 339-49; Konstanze RUDERT, Lorenzo Mattielli in seiner Dresdner Zeit (17381748). Studien zu Leben und Werk eines Bildhauers des Spätbarock in Sachsen, Dissertation an der Technischen Universität Dresden, 1995; Ingeborg SCHEMPER-SPARHOLZ, Der Bildhauer Lorenzo Mattielli. Die Wiener Schaffensperiode 1711-1738. Skulptur als Medium höfischer und sakraler Repräsentation unter Kaiser Karl VI, Universität Wien, 2003 (niepublikowana habilitacja); ead., „Der Bildhauer Lorenzo Mattielli und seine Rolle als Vermittler oberitalienischer Gestaltungsprinzipien in der dekorativen Skulptur und Plastik des Spätbarock in Mitteleuropa", $B a$ rockberichte. Informationsblätter des Salzburger Barockmuseums zur bildenden Kunst des 17. und 18. Jahrhuderts, LXI: 2013, s. 5-21; Konstanze RUDERT, „Lorenzo Mattielli zwischen Wien und Dresden”, ibid., s. 74-83; Jakub SITO, "«Ausgeführt werden soll das Epitaph von den ersten Hofbildhauer». Der Warschauer Auftrag Lorenzo Mattiellis Zur Errichtungsgeschichte, Technologie und Deutung”, ibid., s. 96-106. Na temat związków łączących rzeźby Redtlera z dorobkiem Lorenza Mattiellego zob. OLEŃSKA, Jan Klemens Branicki..., s. 121-122; SITO, „Fenomen rzeźb...”, s. 101-103.

${ }^{81}$ Elfriede BAUM, Giovanni Giuliani, Wien 1964; Ingeborg SCHEMPER-SPARHOLZ, „Bemerkungen zur Stilbildung bei Giovanni Giuliani”, Sbornik praci Filosofické fakulty brněnské univerzity XLII-XLIV, Řada Uměnovědná (F) Č. 37-39, 1993-9, s. 59-74; RONZONI, Giovanni Giuliani..., passim.
} 


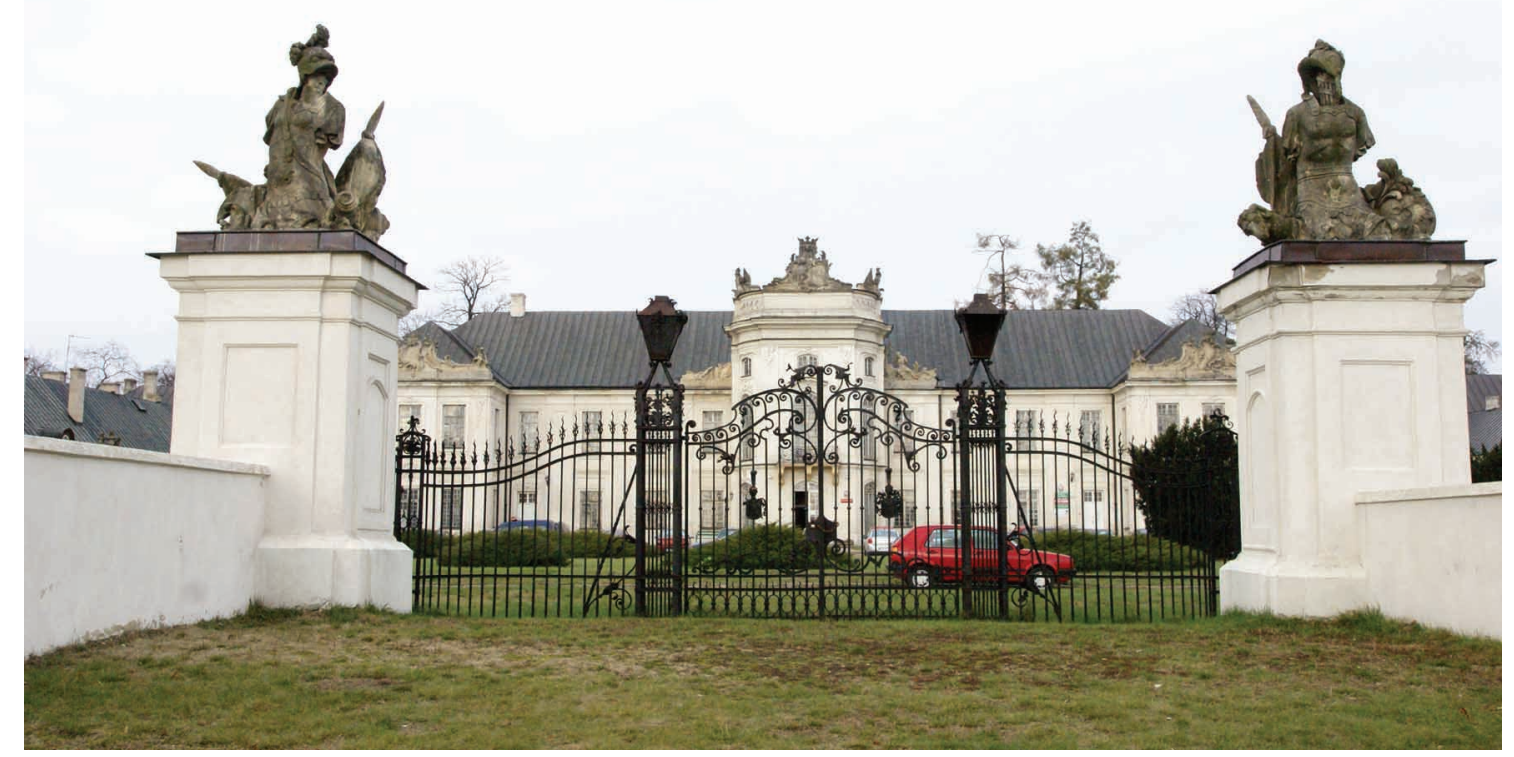

9. Jakub Fontana (projekt), Johann Chrisostom Redtler (wspótprojekt $i$ wykonanie), dekoracja rzeźbiarska bramy południowej w rezydencji Potockich w Radzyniu Podlaskim, ok. 1750-1763. Fot. Jakub Sito

puttów - kamienne rzeźby zdobiące klatkę schodową wiedeńskiego pałacu Liechtensteinów (1705-1706). Te charakterystyczne, zażywne i zabawne, kapryśne postacie dziecięce wprost uderzająco przypominają kompozycje Redtlera z Wilanowa czy Radzynia Podlaskiego, Zamku Królewskiego w Warszawie czy licznych stołecznych nagrobków (np. Jana Jerzego Przebendowskiego i Doroty Henrietty z Przebendowskich Bielińskiej w kościele Reformatów, Marii z Sobieskich Wesslowej w kościele Sakramentek czy Marii Anny Franciszki Brühlowej u Kapucynów). Odgrywane przez Redtlerowskie putta swoiste scenki (alegorie uczuć, pór roku, stron świata itp.) naśladują pełne werwy i niezamierzonego humoru aktorstwo rzeźb Giulianiego.

Jednak nie tylko pojedyncze rzeźby czy grupy rzeźbiarskie Wiednia inspirowały Redtlera, lecz także partie architektury z nimi związane - galerie, attyki, portale, portyki, schody, bramy czy parkany. Mała architektura i rzeźba pałacowych elewacji oraz ich bezpośredniego otoczenia stolicy cesarstwa (dodajmy, iż do dziś dość słabo przebadana, najczęściej anonimowa) stoi u genezy charakterystycznych Redtlerowskich attyk czy bram zdobionych figurami bóstw, sfinksami, wazami i panopliami (il. 9). Te ostatnie, wiązane w charakterystyczne pęki uzbrojenia osadzonego wokół zbroi rycerskiej, ruchliwe i plastyczne niczym ożywiona materia (znane choćby z rezydencji w Radzyniu), wiele zawdzięczają dekoracji gmachów Kancelarii Czeskiej, pałacu Althanów czy Batthyanych ${ }^{82}$.

Co bardzo ważne, Redtler miał niezwykłą zdolność adaptacji do wymagań architekta i bezwzględnego podporządkowania własnej wyobraźni wymaganiom kompozycji architektonicznej zarówno w szerokim planie, jak i wyodrębnionych partiach. Spełniał w ten sposób duże oczekiwania najważniejszego architekta, z jakim przyszło mu współpracować w Warszawie - Jakuba Fontany. Można zaryzykować tezę, iż Fontana celowo dobrał sobie do współpracy Redtlera ze względu na jego łatwość adaptacji do cudzych projektów.

${ }^{82}$ SCHEMPER-SPARHOLTZ, Der Bildhauer Lorenzo Mattielli. Die Wiener Schaffensperiode..., passim. 
Współpraca ta zawiązała się po roku 1750, kiedy to Fontana po śmierci głównych architektów saskich przejął większość rynku budowlanego na potrzeby magnatów związanych z Warszawą. W latach 50. i 60. zawiązał się rodzaj spółki artystycznej pod egidą Fontany z udziałem Johanna Chrisostoma Redtlera jako rzeźbiarza i Michaela Dollingera jako kamieniarza ${ }^{83}$; każdy z nich dysponował zespołem własnych pomocników. To swoiste konsorcjum budowlane obsługiwało place budowy wielkiej liczby nowo wznoszonych pałaców magnackich w stolicy oraz w promieniu jej oddziaływania. W jej ramach kamieniarz i rzeźbiarz realizowali projekty Jakuba Fontany, dostosowując się do jego pełnego rozmachu, malowniczego stylu rokokowo-klasycyzującego o rzymsko-paryskiej genezie. Nie oznacza to jednak, że udział Redtlera w tych przedsięwzięciach ograniczał się wyłącznie do egzekucji projektów Fontany i nie odznaczał się własnym wkładem koncepcyjnym.

Współpraca z Jakubem Fontaną miała na pewno określone ramy i rządziła się ustalonymi regułami, w myśl których rzeźbiarz, zgodnie z powszechną praktyką budowlaną XVIIXVIII w., pozostawał przede wszystkim egzekutorem zamysłów i koncepcji architekta od projektu ogólnego po rozwiązania szczegółowe ${ }^{84}$. Jednak w świetle przekazów źródłowych Redtler jawi się jako twórca o pewnym stopniu suwerenności, będący autorem projektów rysunkowych i modeli rzeźb, a także detalu architektonicznego. O projektowych umiejętnościach rzeźbiarza świadczą same dzieła oraz fragmenty korespondencji jego głównych zleceniodawców - hetmana Jana Klemensa Branickiego i generała artylerii litewskiej Eustachego Potockiego.

Zachowane do dziś wspaniałe figury Herkulesa walczącego z hydrą lernejską i smokiem Ladonem, zdobiące szeroką bramę dzielącą cour d'honeur i avant cour pałacu Branickich w Białymstoku, na mocy kontraktu z października 1757 r. miał do marca roku następnego wykonać Johann Chrisostom Redtler ${ }^{85}$. Zgodnie z umową miały one powstać „podług abrysu”. Autorem owego projektu był nikt inny, jak właśnie ów rzeźbiarz, który, zgodnie z korespondencją hetmana, w roku 1755 wykonał ,modele czyli abrysy osób na bramę w Białymstoku" ${ }^{\prime 6}$. Z kolei w sierpniu 1757 z listu burgrabiego radzyńskiego Adama Woźniackiego do Eustachego Potockiego dowiadujemy się, iż „Pan Redler za odebraniem abrysu czyli projektu na Herkulesów da rezolucyą, na który czas podejmie się robić i siła kosztować będą" ${ }^{87}$. Dodatkowy „dowód rzeczowy” na kompetencje projektowe Redtlera znajdujemy w postaci rysunku przechowywanego w Gabinecie Rycin BUW (il. 10). Widoczny na nim fragment bramy z figurą Herkulesa nosi wszelkie cechy rysunku rzeźbiarza, nie zaś architekta - cokół i fragment murku narysowane są pobieżnie i dość płasko, podczas gdy cała uwaga autora skupia się na rzeźbie, silnie modelowanej lawowaniem i noszącej cechy stylu indywidualnego, bliskiego właśnie Redtlerowi. Na rzeźbiarza wskazują także ołówkowe poprawki w określeniu kształtu ręki chwytającej maczugę.

Tego rodzaju herkulejskie przedstawienia bramne zarówno od strony ideowej, jak i formalnej bliskie były szczególnie fundacjom z kręgu dworu Habsburgów (Schönbrunn w Wiedniu, Zamek Królewski w Pradze). Znał je z pewnością Johann Chrisostom Redtler

\footnotetext{
${ }^{83}$ BARTCZAKOWA, Jakub Fontana ..., passim; Zuzanna PRÓSZYŃSKA, „Dollinger (Delinger, Dölinger) Michał”, [w:] Stownik artystów polskich ..., t. II, Wrocław-Warszawa-Kraków-Gdańsk 1975, s. 79-80.

${ }^{84}$ Zob. przyp. 1; zwłaszcza: MONTAGU, Roman Baroque Sculpture..., passim.

${ }^{85}$ Anna OLEŃSKA, „Wątki heroiczne w programie dekoracji białostockiej rezydencji Jana Klemensa Branickiego”, [w:] Dwory magnackie w XVIII wieku. Rola i znaczenie kulturowe, red. Teresa KOSTKIEWICZOWA, Agata ROĆKO, Warszawa 2005, s. 245-264.

${ }^{86}$ Teki Glinki ,Warszawa, Narodowy Instytut Dziedzictwa, teka 339, s. 4-6, 8-10.

${ }^{87}$ GOMBIN, Inicjatywy artystyczne..., s. 143.
} 


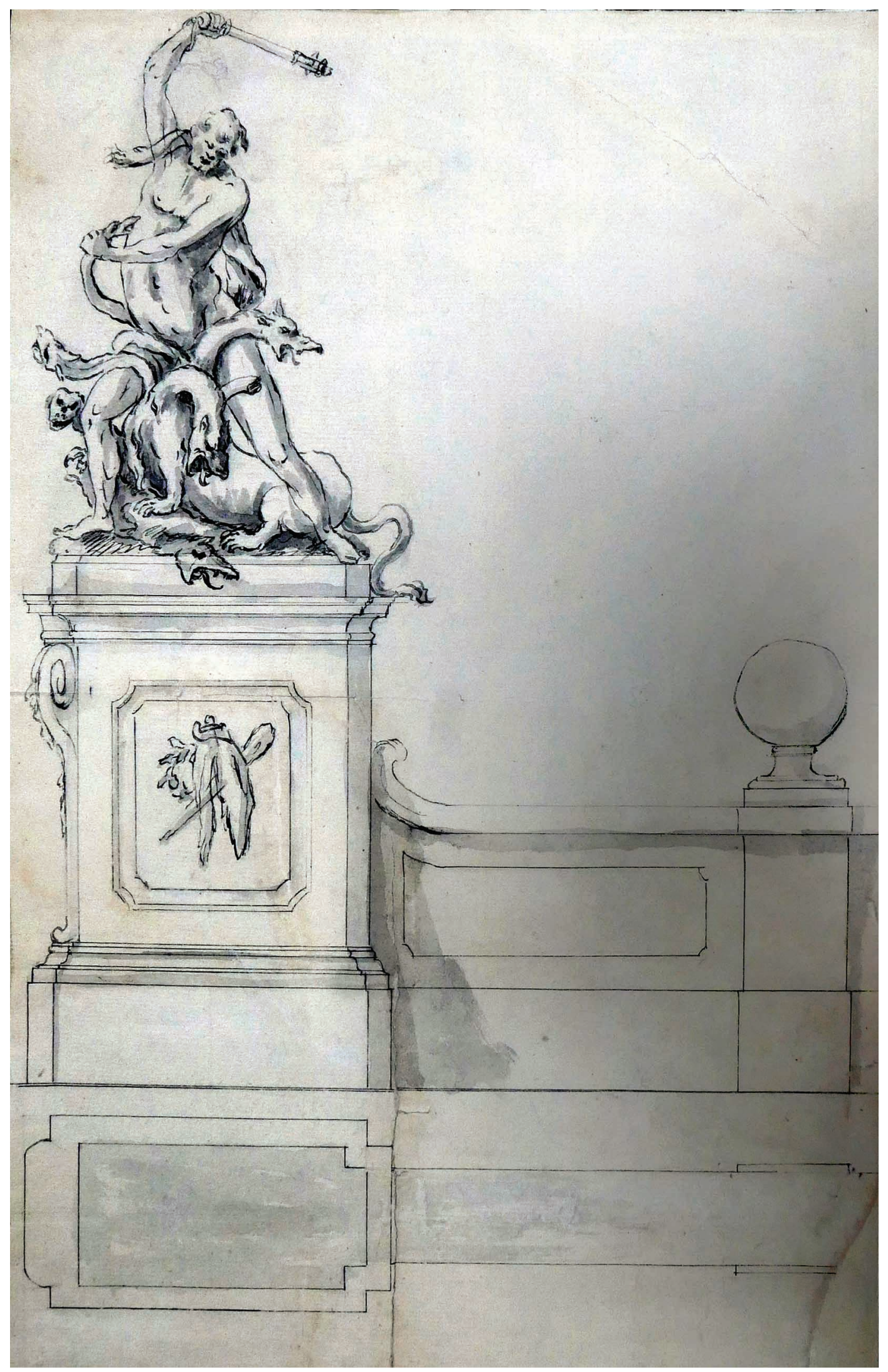

10. Johann Chrisostom Redtler (?), projekt rysunkowy rzeźby Herkulesa na cokole, fragment bramy na dziedziniec honorowy pałacu Branickich w Białymstoku, Warszawa, Gabinet Rycin BUW, Zbiór Królewski P. 187 nr 121. Fot. BUW 


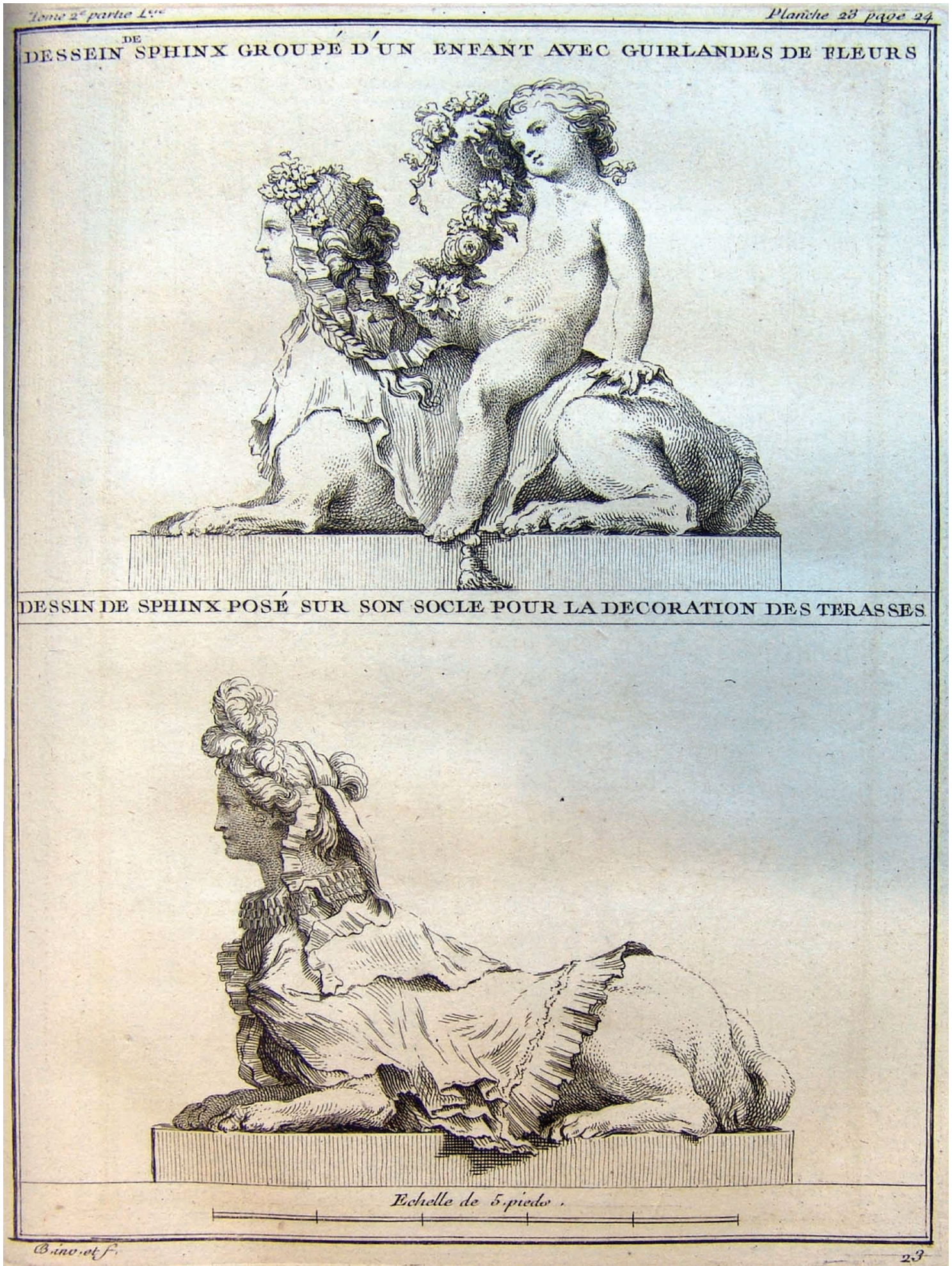

11. Projekt rzeźb sfinksów z De la distribution de maisons de plaisance et la décoration des édifices en général Jean-François'a Blondela (Paris 1737-1738), plansza 23. 


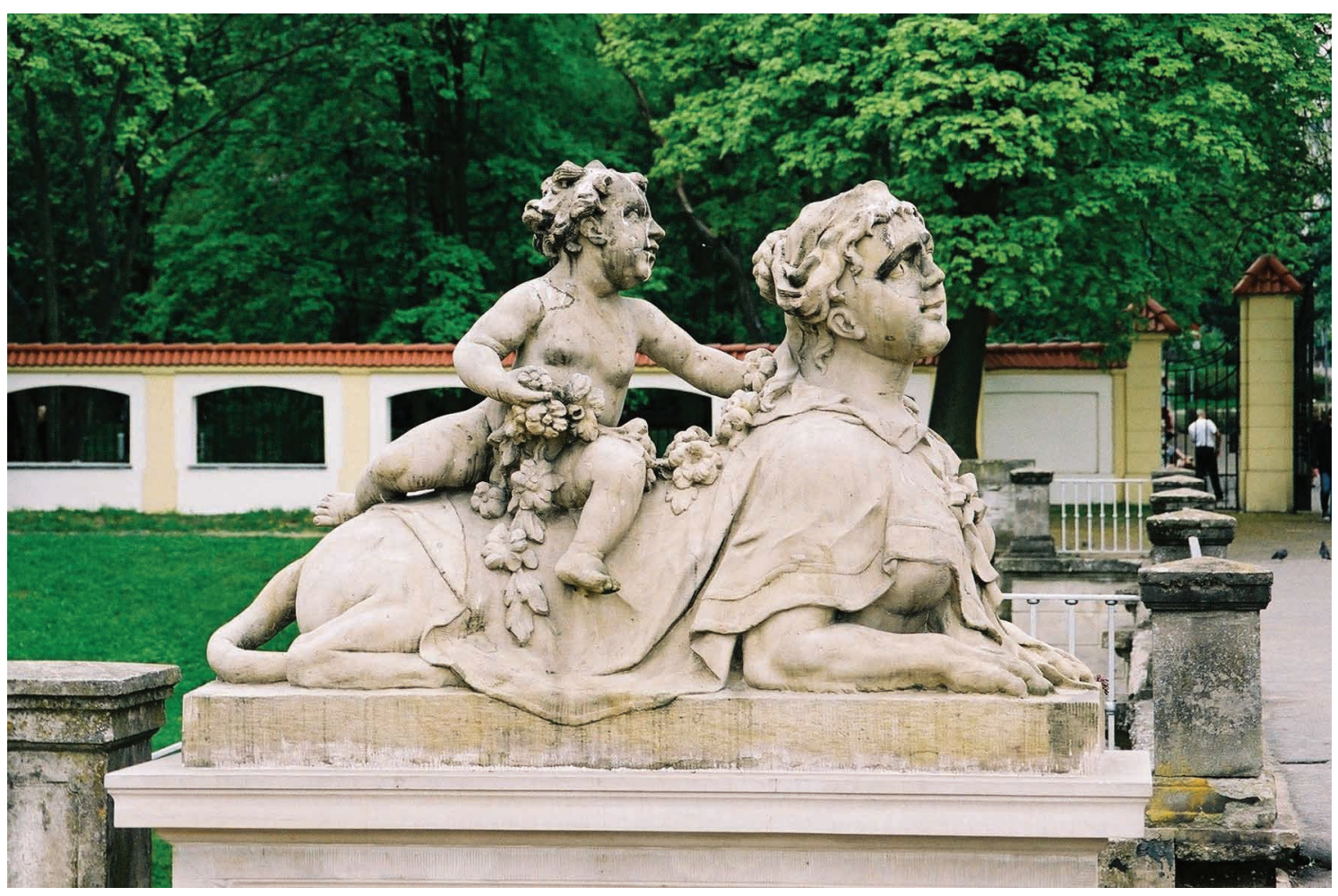

12. Johann Chrisostom Redtler (projekt $i$ wykonanie), rzeźba sfinksa z puttem w ogrodzie pałacu Branickich w Białymstoku, 1752. Fot. Jakub Sito

przybyły z terenów cesarstwa i tam wyedukowany, nie znał natomiast żaden z ówczesnych architektów hetmańskich (głównie Jan Henryk Klemm), reprezentujących inną, północnoeuropejską, a przede wszystkim francuską tradycję. Można przypuszczać, że w tym konkretnym przypadku to właśnie do rzeźbiarza należało pierwsze słowo w procesie projektowania.

Nie można wykluczyć, że projektując białostockie kompozycje rzeźbiarz posługiwał się rysunkami czy rycinami z kolekcji własnej bądź ze zbiorów swego pryncypała czy współpracujących z nim architektów. Jednak i w takiej sytuacji można pokusić się o obronę suwerennej postawy twórczej Redtlera. Jego stosunek jako rzeźbiarza do konkretnych pierwowzorów graficznych, które były mu podsuwane w Białymstoku zarówno przez Branickiego - zleceniodawcę, jak i Fontanę - generalnego projektanta, można dobrze przeanalizować na przykładzie sfinksów powstałych do białostockiego ogrodu w roku 1752. Jak wykazała Anna Oleńska wzorem były tu sztychy Jean-Françoise Blondela z dzieła De la distribution des maisons de plaisance, et de la decoration des edifices en general (17371738), dla których z kolei ogólny wzór stanowiły rzeźby ogrodu wersalskiego $\mathrm{z}$ końca poprzedniego stulecia ${ }^{88}$. Blondel przetworzył te ostatnie w duchu malowniczości (dotyczy to zwłaszcza figur chłopców z girlandą dosiadających mitycznych zwierząt), generalnie jednak utrzymał XVII-wieczną solenność i posagowość sfinksów (il. 11) ${ }^{89}$. W stosunku do propozycji Blondela Redtler poszedł w kierunku dalszej malowniczości i rokokowej swobody a nawet pewnej frywolności (il. 12). Zalotnie przechylone głowy sfinksów, a nawet ich łapy i torsy nabierają cech kobiecych, zmysłowych, dotykalnych.

\footnotetext{
${ }^{88}$ OLEŃSKA, Jan Klemens Branicki..., s. 45.

${ }^{89}$ Jean-François BLONDEL, Traité de l'architecture dans le goût moderne. De la distribution de maisons de plaisance et la décoration des édifices en général, t. I, Paris 1737, t. II, Paris 1738.
} 
Zażywnej twarzy towarzyszy półuśmiech, włosy upięte są w wymyślną, ale realistycznie potraktowaną fryzurę, pierś zwierzęcia zmienia się w pierś kobiecą - Redtler wyraźnie modyfikuje graficzny wzór w duchu środkowoeuropejskiego rokoka.

Redtlerowi zdarzało się przerabiać pracę innego rzeźbiarza według własnego projektu. Tak było w przypadku dekoracji attyk i szczytów warszawskiego pałacu Branickich, których elementy sprowadzono przed majem 1743 r. z Gdańska. Józef Kurdwanowski, rezydent pałacu warszawskiego i doradca artystyczny hetmana, donosił Branickiemu „o kamiennej robocie gdańskiej”, w skład której wchodziły „dzieci wszystkie, waza i niektóre armatury [które] są dobre, sztuka zaś przednia i z nią cztery armatury te koniecznie poprawione być muszą, nad czym Redler sobie głowę łamie y abrys gotuje [podkreślenie - J. S.] jakim to sposobem poprawić będzie można i spodziewam się że on to ładnie wymoderuje [...] jak tedy da mi na to projekt [podkreślenie - J. S.] y siła ta repreacja kosztować będzie [...] oznajmię" ${ }^{90}$. Z powyższego opisu można wnioskować, że wykonane w Gdańsku rzeźby nie zadowalały Kurdwanowskiego i polecił on Redtlerowi ich przeróbkę, ten zaś wykonał ją według własnego projektu, nadając im zapewne nowy wyraz i przynajmniej częściowo nową kompozycję.

Redtler był także projektantem detalu architektonicznego, a nawet konsultował większe projekty budowlane. Na pograniczu detalu rzeźbiarskiego i architektonicznego sytuują się „,wazy kamienne [które miał] robić podług dawnego kontraktu z 1766 r., [a które] Pan Redler sztukator podejmuje się [...] abrys na też wazy podpisany ręką J.W. Pana pokazywał mi”. W 1755 r. Redtler miał robić nieokreślone ,modele kapiteli i baz do kolumn w pałacu na Podwalu" "91 . Bardziej znana jest sprawa nowego ukształtowania westybulu pałacu w Białymstoku z 1755 r. według projektu Jakuba Fontany z udziałem nieodłącznych rzeźbiarza Redtlera i kamieniarza Dollingera. Według projektu swego szefa i protektora miał Redtler samodzielnie wykonać modele bogatych i skomplikowanych w rysunku kapiteli i baz kolumn przeznaczonych do odlania w ołowiu. Warszawski korespondent Branickiego informował swego pryncypała: „J. Panu Fontaniemu przypomniałem o kapitele i cokoły; powiedział, że pamięta o nich i przypomniał Redlerowi model na nie, który ponieważ już teraz skończył, obiecał tenże J.P. Fontana uczynić kontrakt z ludwisarzem o odlanie onych"92.

Najbardziej zaskakująjednak informacje o zgoła architektonicznych kompetencjach Redtlera. W maju 1753 r. ${ }^{93}$ Branicki domagał się udziału między innymi rzeźbiarza w przeprojektowaniu nowo powstającego buduaru w rezydencji warszawskiej, pisząc do swego warszawskiego rezydenta: „Pana Rychtera, Redlera i maurmaistra sprowadź Waszmość Pan do buduaru, niech obaczą i zważą, jeżeli dach, jaki jest w abrysie, ma proporcya, jeżeli nie jest ogromny i nie będzie ciężki, lepiej się zatrzymać z tym dachem, a niech projekt $\mathrm{Ci}$ wszyscy z sobą się naradziwszy zrobią i mi tu przyślą na pokazanie". Nikt inny jak właśnie Redtler miał się odnieść do kwestii kompozycji rzeźby putta z wazonem wieńczącej dach: „Figura na dachu ma być zbyt wielka, niech Pan Redler nie trzyma się abryssu, podług swego zdania ma robić żeby była proporcjonalna i niezbyt cięszka do tego dachu"94.

Wśród warszawskich rzeźbiarzy hetmana Jana Klemensa Branickiego był także Johann Samuel Contesse (Contessa) - znany snycerz-ornamentalista. Realizował on głównie modne, rokokowe boazerie, między innymi w białostockich apartamentach Jana

\footnotetext{
90 OLEŃSKA, Jan Klemens Branicki..., s. 138.

91 Teki Glinki, teczka 332, s. 3-5.

92 Archiwum Roskie, Warszawa, AGAD, Korespondencja, 77, kopiarz 14: I. Koziebrodzki do J. K. Branickiego, s. 60.

93 OLEŃSKA, Jan Klemens Branicki..., s. 109.

94 Ibid., s. 97.
} 
Klemensa i Elżbiety Branickich w latach 1753-1754. Snycerz ów wykonał jednakże również rysunkowy projekt karety zwanej ,paryską" 95 . I ten przypadek dowodzi, że umiejętności warszawskich rzeźbiarzy wykraczały, i to znacznie, poza kompetencje czysto wykonawcze, określane niemieckim pojęciem Ausführung.

Przykładem rzeźbiarza w pełni samodzielnego, pozbawionego ,partnerstwa” projektowego w osobie architekta, był znakomity artysta późnych czasów Augusta III - Pierre Coudray $^{96}$. Urodzony w Paryżu w 1713 r., związany był przez większość życia z Dreznem. Kształcąc się początkowo pod pieczą ojca, rzeźbiarza François'a Coudray'a, miał w latach 1743-1745 przebywać w Rzymie, by następnie wrócić do Drezna, gdzie nabrał ogłady rzeźbiarskiej pod kierunkiem słynnego Lorenza Mattiellego. Pozostawał głównie w dyspozycji hrabiego Heinricha von Brühla, premiera saskiego i ministra króla polskiego Augusta III. W związku z wybuchem wojny siedmioletniej, wzorem wielu artystów drezdeńskich Pierre Coudray przeniósł się do stolicy Polski, gdzie przebywał w latach 1759-1765, o czym można znaleźć wzmianki w źródłach. Tu pracował dla Heinricha i Marii Anny Franciski von Brühl, głównie nad dekoracją ich pałacu przy ulicy Wierzbowej w Warszawie ${ }^{97}$. Francuski rzeźbiarz był zatrudniany także przez polską magnaterię i Kościół. Do jego zleceniodawców należeli Czartoryscy w Wilanowie ${ }^{98}$, Cetnerowie w Krakowcu ${ }^{99}$ czy Braniccy w Białymsto$\mathrm{ku}^{100}$. Stanisław August zaproponował mu w 1765 r. stanowisko profesora w planowanej Akademii Sztuk w Warszawie ${ }^{101}$. Artysta zdecydował się jednak na powrót do Drezna, jako że już w lutym 1764 r. otrzymał profesurę w utworzonej tam akademii sztuk pięknych. Jako

\footnotetext{
95 Ibid., s. 86.

${ }^{96} \mathrm{Na}$ temat Coudray'a zob. Tadeusz MAŃKOWSKI, Rzeźby zbioru Stanisława Augusta, Kraków 1948; Ernst SIGISMUND, „Coudray (Coudre) Pierre”, [w:] Allgemeines Lexikon der Bildenden Künstler von der Antike bis zum Gegenwart, red. Ulrich THIEME, Felix BECKER, t. XVII, Leipzig 1912, s. 570; Jakub SITO, „Coudray (Coudre) Pierre”, [w:] Saur Allgemeines Künstler-Lexikon der Bildenden Künstler aller Zeiten und Völker, t. 21, München-Leipzig 1999, s. 541-542; Elżbieta ŻYŁKO, ,Architektura i urbanistyka Tykocina w XVIII wieku w świetle nieznanych materiałów archiwalnych”, Kwartalnik Architektury i Urbanistyki, VII: 1962: nr 2, s.109-110, 117-119, aneksy VII-IX; Mariusz KARPOWICZ, „Malarstwo i rzeźba czasów saskich", [w:] Sztuka Warszawy, red. Mariusz KARPOWICZ, Warszawa 1986; Sabine WILDE, Gottfried Knöffler (1715-1779). Ein sächsischer Hofbildhauer in der Zeit des Stilwandes, Dresden 2010, s. 15, 30, 58, 60, 66, 169-171, 173-174, 322, 323, 329, 330; SITO, „Sculptors from the Court...”, s. 199-262; Jacek GAJEWSKI, „Pomnik Czarnieckiego w Tykocinie - jego autor i wykonawca - Coudray i Redler?”, [w:] Laudator Temporis Acti. Studia z dziejów sztuki i kultury ofiarowane Księdzu Janowi Niecieckiemu w 65 rocznice urodzin, red. Irena ROLSKA, Krzysztof GOMBIN, Krzysztof PRZYLICKI, Lublin 2015, s. 183-217; Jakub SITO, „Polskie lata Pierre’a Coudraya - początki klasycyzmu w rzeźbie polskiej. Die polnischen Jahre des Pierre Coudray - die Anfaenge des Klassizismus in der polnischen Skulptur", [w:] Johann Joachim Winckelmann i / und Stanisław Kostka Potocki. Mistrzowie i uczniowie / Meister und Schüler, red. Paweł JASKANIS, Max KUNZE, Mainz und Ruhpolding-Warschau 2016, s. 55-72; id., ,Zespół rzeźb ogrodowych w rezydencji Walewskich-Grabińskich w Walewicach. Nieznane dzieła rzeźbiarzy warszawskiego rokoka - Pierre'a Coudray'a i Johanna Chrisostoma Redtlera", [w:] Historia - Konserwacja - Rewitalizacja. Funkcjonowanie rezydencji regionu tódzkiego w kontekście doświadczeń europejskich. Prace dedykowane pamięci Profesora Leszka Kajze$r a$, red. Tadeusz BERNATOWICZ, Piotr GRYGLEWSKI, Krzysztof STEFAŃSKI, Łódź 2016, s. 341-360.

${ }^{97}$ Jakub SITO, „Warszawski pałac Sanguszków w rękach Heinricha Brühla”, [w:] Wokół Sanguszków. Dzieje - sztukakultura. Materiały I Ogólnopolskiej Konferencji Naukowej 29-30 czerwiec 2006. Ratusz, Muzeum Okręgowe w Tarnowie, Tarnów 2007; id., „Das Sendomirsche Palais - die Warschauer Residenz von Heinrich Brühl an der WierzbowaStraße. Aspekte der Architektur und Stadtplanung", [w:] Barocke Repräsentation in der Ära des sächsischen Ministers Heinrich Graf von Brühl (1738-1763), red. Tomasz TORBUS, Leipzig 2014, s. 85-100.

${ }^{98}$ SITO, „Polskie lata Pierre'a Coudraya...”, s. 289-305.

99 Ostatnio J. SITO, , «J'ai accordé avec le Sieur Coudray Sculpteur du Roy statues du pierre...». O dekoracji rzeźbiarskiej rezydencji Cetnerów w Krakowcu", [w:] Residentia in tempori belli et pacis. Materiały do badań i ochrony założeń rezydencjonalnych i obronnych, red. Piotr LASEK, Piotr SYPCZUK, Warszawa 2019, s. 226-245.

100 GAJEWSKI, „Pomnik Czarnieckiego w Tykocinie...”, s. 183-217.

${ }^{101}$ MAŃKOWSKI, Rzeźby zbioru Stanisława Augusta..., passim.
} 
akademik musiał być nader biegły w wykonywaniu modeli swych rzeźb wraz cokołami i ich architekturą, a być może biegłość ta obejmowała również i inne partie architektury, szczególnie styczne z rzeźba, jak gzymsy, attyki, nadokienniki, okapy, portale. Jako poważany profesor akademicki z całą pewnością musiał dobrze radzić sobie prowadząc na zajęciach kompozycję modela czy detalu architektonicznego. Przegląd jego polskich dokonań wskazuje, iż w pełni samodzielnie modelował rzeźbę figuralną, bywało, że w oparciu o grafikę włosko-francuską czy też tradycję antyczną, ale zawsze zgodnie z własną koncepcją kompozycyjną. W Polsce był Coudray zarówno rzeźbiarzem-wykonawca, jak i projektantem oraz twórcą modeli, według których pracowali jego podwykonawcy i inni rzeźbiarze. Już na samym początku swego polskiego epizodu wykonał w 1759 r. gipsowe modele kapiteli do fasady kościoła Św. Krzyża w Warszawie, które następnie odkuł sam Johann Georg Plersch(! $)^{102}$. Jak ustalił ostatnio Jacek Gajewski, Coudray był także projektantem i autorem modelu słynnego pomnika Stefana Czarnieckiego w Tykocinie, nie zaś, jak się dotąd powszechnie przypuszczano, jego wykonawcą. Odkuł go bowiem wspominany Johann Chrisostom Redtler, nadając mu zresztą własne, charakterystyczne środkowoeuropejskie piętno ${ }^{103}$.

Z uwagi na ogromne straty w materiale źródłowym powyższe obserwacje dotyczące projektowych kompetencji rzeźbiarzy warszawskich oparte są rzecz jasna na danych wyrywkowych. Do poszczególnych artystów odnoszą się one w sposób niejednorodny. W przypadku Plerscha mamy do czynienia z największą ilością zachowanych projektów rysunkowych, zaś w odniesieniu do Redtlera zachowała się największa liczba wzmianek archiwalnych, trudno jednak oprzeć się wrażeniu, że jest to zaledwie znikoma część materiału pierwotnego. Nasuwające się wnioski muszą być tym samym formułowane nadzwyczaj ostrożnie, a postawa badawcza winna cechować się krytycyzmem i gotowością do rewizji. To, co wszakże uderza w sposób jak się wydaje nie budzący wątpliwości, to ścisła współpraca warszawskich rzeźbiarzy z architektami, nierzadko przybierająca postać swoistych spółek architektoniczno-rzeźbiarskich. Dodajmy, iż chodzi tu o architektów wybitnych, wyróżniających się w skali polskiej, a nawet środkowoeuropejskiej, jak Carlo Antonio Bay, Carl Friedrich Pöppelmann, Johann Sigmund Deybel czy Jakub Fontana, pozostających w służbie dworu królewskiego i wielkich panów, a także stołecznych domów zakonnych, najczęściej silnie zależnych od magnaterii. Owi architekci o skrystalizowanych osobowościach twórczych i wyrazistej postawie artystycznej zakorzenionej w świecie wzorów europejskich przedkładali ofertę atrakcyjną i cenioną na warszawskim rynku zleceń. Jej składową była chyba w większym stopniu niż w innych ośrodkach Rzeczypospolitej stojąca na bardzo wysokim poziomie rzeźba, wchodząca w skład wyposażenia i wystroju tak wewnętrznego, jak i w wyjątkowym bogactwie zewnętrznego. Architekci i rzeźbiarze aktywni na stołecznych placach budów siłą rzeczy zmuszeni byli tedy do ścisłej kooperacji. W Warszawie, odmiennie też niż w większości ośrodków polskich, to właśnie architekci z zasady odpowiadali za projekty elementów rzeźbiarskich, często do najmniejszego szczegółu, również w dziedzinach tradycyjnie uznawanych za domenę rzeźbiarzy, jak np. ołtarze. $Z$ drugiej strony twórcy dłuta, zwłaszcza ci wybitni, a takich tu nie brakowało, traktowani byli przez architektów w znacznie większym stop-

${ }^{102}$ SITO, ,Sculptors from the Court...”, s. 199-262.

${ }^{103}$ GAJEWSKI, „Pomnik Czarnieckiego w Tykocinie...”, s. 183-217. 
niu niż gdzie indziej w sposób partnerski. Co bardzo ważne, stała obecność w Warszawie zamieszkałych tu znakomitych architektów pozwalała stołecznym rzeźbiarzom unikać w kontaktach z nimi kłopotliwego pośrednictwa budowniczych realizujących „fabryki”. Nie było to możliwe na prowincji, gdzie kontakt z projektantem ograniczał się niejednokrotnie do jednej, co najwyżej kilku wizyt architekta na placu budowy. Uprzywilejowani w ten sposób rzeźbiarze warszawscy, zwłaszcza ci najzdolniejsi, przyswajali często język projektowy swoich „partnerów” - architektów, a także chłonęli prezentowaną przez nich postawę artystyczną i intelektualną. Projektowali przede wszystkim te partie budowli, które były z rzeźbą najściślej związane - portale, wnęki, attyki, supraporty, a w architekturze sakralnej ołtarze, ambony, nagrobki czy epitafia. W przypadku obiektów o mniejszej skali czy inicjatyw o mniejszym rozmachu to do nich często zwracali się dysponenci, bez potrzeby angażowania całego instrumentarium największych warszawskich budowniczych. Kreujący się na suwerennych twórców, a nawet nazywani doraźnie ,architektami”, jak w przypadku Plerscha projektującego supraportę dla warszawskiej kolegiaty, stołeczni rzeźbiarze starali się godnie zastępować swoich „mocodawców” w dziedzinie artis inventionis. 


\section{Warsaw Sculptors of the Saxon Times as Designers}

One of the main aspects of the activity of a Baroque sculptor's workshop was the design of an art piece in which sculpture was of major importance, both as far as a human figure or figural groups were concerned, and in the case of architectural framings, e.g. a portal, tympanum, wall, gate, altar, tomb, pulpit, and other sacral and secular works. The departure point for every sculpture piece was essentially either a two- or a three-dimensional model approved by the client. The client commissioning a definite piece could either call a competition for the design or address several artists, asking them to prepare such a design. Cases are known of several sculptors bidding for the same order and submitting both drawn models and a 3-D-modelletta. Sculptors like Gianlorenzo Bernini, Alessandro Algardi, François Duquesnoy, Ferdinand Maximilian Brokoff, Johann Baptist Straub, Raffael Donner, or Baltasar Permoser designed so-called small architecture/ elements of bigger edifices or free-standing objects: altars, tombs, epitaphs, and even fragments of architecture, e.g. portals, balustrades, etc. The sculptor-designers were on the one hand renowned artists, permanently employed at royal and aristocratic courts, by higher clergy and monasteries, yet on the other hand active in the cultural peripheries where they would not be confronted by important competition of architects and stonemasons. However, the designing of sculpture works was not only and exclusively the domain of their direct creators. Designs of prestigious works were often commissioned from architects: e.g. Johann Bernhard Fischer von Erlach, Lodovico Burnacini, or from painters: Charles Le Brun or Michael Willman. Sculptors themselves, such as Gianlorenz Bernini, Alessandro Algardi, François Duquesnoy, Ferdinand Maximilian Brokoff, Johann Baptist Straub, Raffael Donner, or Baltasar Permoser designed altars, epitaphs or garden statues. The question of Baroque sculptors participating in designing art pieces, including the figures they would later sculpt, has not been a subject of separate studies in Polish literature. Only minor mentions on the topic have been included in broader studies, monographs on respective sculptors, as well as architects, in synthetic analyses of respective artistic centres, or studies on artistic patronage. These observations have focused mainly on the Warsaw circles, which should not be surprising, since they have been relatively well identified (as compared to other centres of the Polish-Lithuanian Commonwealth), and had a relatively high output.
It is Bartłomiej Michał Bernatowicz (d. 1730) that can be ranked among the Warsaw sculptor-designers; he was active in the second and third decades of the century, running a flourishing and popular studio, or more appropriately said, a sculpting enterprise responsible for the majority of the Warsaw output from ca 1715 to 1730 . He executed sculpting jobs, mainly altars, pulpits, and tombs for Warsaw convent churches: of the Jesuits, Dominicans, Franciscans, Paulites, Piarists, Trinitarians, and others. It is known that independent designs were created in that workshop (e.g. Koden Church high altar); furthermore, Bernatowicz cooperated with Carl Antoni Bay, the most outstanding Warsaw architect of the first four decades of the $18^{\text {th }}$ century; coming originally from northern Italy, and educated in Rome in ca 1700, he was a student of Andrea Pozzo. He cooperated with the latter working on the tomb of Cardinal Michał Radziejowski (1719-21), and was responsible for the design of the figure of the deceased.

However, the major personality among Warsaw sculptors active during the reign of the Saxon House was Johann Georg Plersch, from ca 1735 head of the large royal studio. He contributed to the external and internal sculpture decoration of the first edifices in the capital: the Royal Castle, the Saxon Palace, a substantial part of the newly created and modernized older magnate palaces, garden ensembles or churches. The prominent position of Plersch resulted from his cooperation with the most illustrious Warsaw architects of the Saxon era, mainly royal, meaning Johann Sigmund Deybel and Carl Friedrich Pöppelmann. The style of their design closely echoing the aesthetics of French NeoClassicism with Rococo elements was characterized by restraint and certain rigorism, underpinned with subtlety. The silhouette effect of those palaces was cocreated by a meticulously arranged, yet modest, but tasteful sculpture decoration. Sculpture accents focused at the central composition knots: on mansard roofs, on attics, either full or pilastered/ with balustrade, with a line of statues or sculpture groups, on external stairs, gate ensembles, or walls. Educated mainly on Roman patterns and the Prague Baroque sculpture, thus within the circle of a completely different tradition, Plersch quickly adjusted to the needs of sumptuousness expressed in Warsaw's palace architecture and the circle of its impact. Interestingly, the design sections containing figural decoration were drawn by Pöppelmann taking into 
account Plersch's dynamic sculpting manner, clearly 'ready-made for his chisel'. From the 1740s, Plersch began co-operating with Jakub Fontana, Warsaw's architect of Italian descent. What stands out among the Warsaw architectural works designed by Fontana and decorated by Plersch are the following: the spectacular extension of the Bieliński Palace; the façade of the Church of the Holy Cross with a sumptuous forecourt for coaches; the Rococo fragments of the façade and interior of the Church of the Nuns of the Visitation; and last but not least, the interior of the new Deputies' Chamber in the Warsaw Royal Castle. Furthermore, Plersch may have contributed to the planned construction of the Piarist Collegium Nobilium. Educated in Europe (he had made an Italian and French educational trip), Fontana formed his own unique style, combining elements of Italian High and Late Baroque as well as French Rococo, with a continuously lingering classical component. This style appealed greatly to the background and sensitivity of his regular partner that Plersch was. Both shared Rome-based education and esteem for the tradition of the Seicento art, particularly in its lively expressive variant from the latter half of the $17^{\text {th }}$ century. Both eagerly made references to Bernini and his followers, with Plersch less tempted to classicize, although he remained capable of yielding to the requirements of the clients and the architect in this respect. In the course of the Fontana - Plersch cooperation respective architect's and sculptor's contribution was not clearly discernible. Some of the smaller architectural pieces, or their fragments, were designed by the sculptor himself, who used, however, the style vocabularium of Fontana. Such was the case with the design of the statue of St John of Nepomuk at Trzech Krzyzy Square, or the loggia balconies in the Church of the Holly Cross. Even in the designs of the lateral altars in the Saxon Chapel, designed essentially under C.F.Pöppelmann, Plersch used Fontana's language of forms. As a designer in the strict meaning of the term, Plersch is mentioned in 1746 in the description of the execution of the supraporte over the portal to the sacristy in the Collegiate Church of St John, in the design drawings of the high altar in the Paulinite Church in Leśna, or in the contracts to execute the loggias of the Church of the Holy Cross. The famous epitaph of Jan Tarło from the Piarist Church was 'rendered with Plersch's exquisite art in harmony with his mastery', which may mean at least that he participated in its designing (next to Jakub Fontana).

Another, next to Plersch, most proliferous Warsaw sculptor of the Rococo period was Johann Chrisostom Redtler who came from the territory of the Habsburg Monarchy, most likely Austria. He was very well acquainted with the art of Vienna, not only sculpture, but also small-sized architectural pieces, which is testified to by his later creative cooperation with Warsaw architects, mainly Jakub Fontana. The sculptor had this unusual capacity of adapting to the requirements of the architect, and ruthlessly subduing his own imagination to the requirements of the architectural composition. Redtler was inspired not only by single sculptures or sculpture groups from Vienna, but also architecture segments connected with them: galleries, attics, portals, porticos, stairs, gates, or fences. As seen against the records, Redtler seems to have been an artist of some degree of independence, author of two- and three-dimensional models of sculptures as well as of architectural detail. The designing skills of the sculptor are best testified to by fragments of the correspondents with his main customers: Hetman Branicki and General of Lithuanian Artillery Potocki. They are also confirmed by his very works, mainly the detail of the Potocki Palace in Radzyń, the Branicki Palace in Białystok, or the Brühl Palace in Warsaw. Moreover, Redtler designed architectural details, and even consulted major construction designs; on some occasions, he altered works of other sculptors following his own design. The latter was the case in the decoration of the attics and gables in the Branicki Palace in Warsaw; its elements were imported from Gdansk.

Bearing in mind ample losses in the source materials, the above observations related to designing competences of Warsaw sculptors were for obvious reasons based on fragmented data. These are not found homogenously for respective artists. In the event of Plersch we deal with the largest number of drawing designs, while for Redtler what has been preserved is the biggest number of archival mentions, yet it seems quite obvious that these are all but a fraction of the original records. What strikes, however, with indisputable certainty is the close cooperation that Warsaw sculptors had with architects, frequently taking on the form of a peculiar architectural joint venture. Those architects boasting a well-shaped creative personality and a clear artistic attitude rooted in he world of European models submitted attractive offers, well appreciated in the Warsaw market. Their essential element was highquality sculpture serving as component of both interior furnishing and décor, as well as richness of exterior decoration. Warsaw sculptors, particularly the most talented ones, often adopted that design language of their 'partners' - architects, and also absorbed the artistic and intellectual attitude they presented. They would design first of all those fragments of the buildings that were most strictly connected with sculpture: portals, niches, attics, supraportes, and in sacral architecture altars, pulpits, tombs, or epitaphs. When wishing to have lower- 
-scale pieces and lower-profile projects, clients would often just turn to them directly, without the need to involve all the instrumentation of the largest Warsaw builders. Playing the role of independent artists, to the extent of occasionally being called 'architects', as was in the case of Plersch when he was designing the supraporte for the Warsaw Collegiate Church, Warsaw sculptors made efforts to dignifiedly represent their 'patrons' in the artis inventionis sphere.

Translated by Magdalena Iwińska 